\title{
Primary Health Care Policy Implementation Performance in Bangladesh: Affecting Factors
}

\author{
Md. Mohoshin Ali \\ Ph.D. Candidate at the Graduate School of Public Administration \\ National Institute of Development Administration (NIDA) \\ 118 Moo3, Serithai Road, Klong-Chan, Bangkapi, Bangkok 10240, Thailand \\ E-mail: mohoshin2005@gmail.com
}

Received: Mar. 7, 2018 Accepted: Mar. 26, 2018 Online published: Mar. 28, 2018

doi:10.5296/jpag.v8i1.12782ＵRL: https://doi.org/10.5296/jpag.v8i1.12782

\begin{abstract}
The extent of how health policy implementation performance is taking route at the national level is a very important issue as far as world population levels in relation to the future workforce is concerned. These require properly implementation of health policy by the respective government. This study was tried in unearthing factors related to primary health care policy implementation in Bangladesh. An integrated conceptual framework was developed based on a review of the literature. Primary data were collected from the total population of 424 Upazilla Health and Family Planning Officers (UH\&FPO). Hierarchical multiple regression analysis as a tool of the quantitative method was used. The results revealed that four out of seven explanatory variables were statistically significant and had a unique contribution for the relationships with health policy implementation performance ordering as per the strength; Implementer's Disposition (ID), Clarity of Goals and Objectives (COGAO), Management Dynamics (MD), and Coordination (COORD). The study also envisioned to recommend policy implications as; the policy makers ought to revise the goals and objectives of the health policy that must be specific measurable achievable realistic and timebound (SMART), government should allocate more resources in primary health care, inter-organizational coordination should be strengthened, to prominence on innovation for effective health care delivery using technology, research and development and health and well-being management, to motivate health providers regarding their responsibility, devotion and attitude, to get local support specially from local government and administration, and to ensure gender equality deploying female doctors as UH\&FPO. Finally, the findings expected to benefit the society considering the contribution of new knowledge generated in the field of policy implementation.
\end{abstract}


Keywords: health policy implementation in Bangladesh, health policy, policy implementation, policy evaluation, policy implementation performance, policy implementation performance in primary health, policy implementation level in primary care

\section{Introduction}

Health care is indispensable for increasing the productivity of human beings. To sustain a healthy nation, various governments all over the world have in cooperated health budget in their expenditures through enabling policies. American came with their first health policy in 1854, Britain in 1948, Germany in 1880, France in 1880, China in 1949, while Japan in 1927 respectively (Wikipedia, 2017). However, in Bangladesh, it was introduced in 2000 and redefined the policy in 2011 (Ministry of Health and Family Welfare, 2012). The international community through WHO has also been very concern about the state of health worldwide, many conferences, agreement have been held resulting in member national adoption through policies; example; The Alma Ata Declaration (1978), The World Summit for Children (1990), International Conference on Population and Development (1994), Beijing Women's Conference (1995), World Health Summit held annually in Berlin, German, international, classification of functioning, disability and health, the international classification of health intervention, .international code of marketing of breast-milk (1981), framework convention on tobacco control (2003), global code practice on the international recruitment of health personnel (2010). The notion of coming up with relevant policies on health among government has been embraced and instituted, however, the problem of policy implementation performance has been one of the serious handicaps in various government more so developing countries. The magnitude of how health policy implementation performance is taking route at the national level is a very important issue as far as world population levels in relation to the future workforce is concerned. This is supported by the way how countries have been affected by various world killer diseases such as HIV/AIDS, cancer, tuberculosis, malaria, heart disease etc. this coupled by poverty and aging population, health policy implementation is seen to be vital for sustained development. To date, the world population is at 7.5 billion (United Nations, 2017). Those suffering from cancer 1.6 million die every year, 35 million people are infected with HIV/AIDs, about 900 thousand people lost their lives in Tuberculosis in every year, 6.7 million dies for stroke, 7.4 million dies for heart diseases, 1.5 million people die every year for diabetic related causes and the aged are $8.5 \%$ and those below the age of $0-14$ are $26.11 \%$ (WHO, 2016). All these cohorts require properly implementation of health policy by the respective government. However, it is noteworthy that not all countries over the world have the same factors affecting health policy implementation. This study was concerning to examine the situation of primary health care at the sub-district level in Bangladesh. Generally, the country has a population of 158.9 million and maternal mortality and child mortality rate were 1.7 and 33 in per thousand live birth respectively, total fertility rate was 2.11 and ageing rate was $6 \%$ etc. (NIPORT \& Associates, BDHS, $2014 \&$ BBS, 2016) and there is also growing concern regarding plateauing of the total fertility level (TFR), aging, adolescent reproductive health, maternal health, threat of HIV/AIDS/STD, child health, morbidity, nutrition, early pregnancy, unwanted pregnancy, unmet contraceptive needs, health hazard due to climate change. This has been majorly 
experienced in the United Kingdom, the United States of America, France, Canada, Japan, Malaysia, and Thailand. However, in Bangladesh, this can only be achieved if factors affecting policy implementation performance is known and the rate of their effectiveness is determined. The study was intended to find out the influencing factors affecting implementation performance in primary health care and perceived the level of implementation performance by the sub-districts level health administrators Upazila Health and Family Planning Officers (UH\&FPOs) in primary health care facilities in Bangladesh.

\subsection{Research Objectives}

i. To assess the level of health policy implementation performance in primary health care in the sub-district level health facilities in Bangladesh.

ii. To examine the policy related, organization related, individual level and local level support factors affecting health policy implementation performance in primary health care in the sub-district level health facilities in Bangladesh.

iii. To determine the most influencing factors affecting health policy implementation performance in primary health care in the sub-district level health facilities in Bangladesh.

iv. To recommend policy implication of the findings for the policy makers, implementers, and future research.

\subsection{Significance of the Study}

The health policy implementation performance in primary healthcare is a great challenge considering the factors affecting the implementation performance in public facilities of primary level for better, equitable and efficient health services and coverage for the entire citizen of Bangladesh. There are limited studies yet to identify the influencing factors affects in primary health care policy implementation performance especially in government primary level health facilities in Bangladesh. Therefore, the research study was tried to assess the factors affecting health policy implementation performance in primary health care in Bangladesh. The study has also intended an endeavor to make understand the policy makers and implementers were to work for better implementation performance of health policy especially for the poor people in the rural areas. The study was also expected to contribute in the literature of public health policy implementation research in primary health care in Bangladesh and will be available for scholars, researchers, health management personnel and the policy planners and implementers. The study was focused on the perceived level of health policy implementation performance in primary health care in Bangladesh.

\section{Literature Review}

\subsection{Policy Implementation}

Policy implementation has been well-defined by many academics from different viewpoints. Nakamura \& Smallwood, (1980: p.1) pointed out that "policy implementation is the set of activities and operations undertaken by various stakeholders toward the 
achievement of goals and objectives defined in an authorized policy." In addition, Sabatier \& Mazmanian, (1980, pp.47-65) refers "implementation is evolutionary and is influenced by the ideological, political and economic climates in which it occurs, and it becomes harder and more varied as the policy objectives filter down through the bureaucratic structure of the implementing organization." Similarly, Stewart et al., (2008: p.104) refers "implementation is a stage of policy-making process in which actors, organizations, procedures techniques of control and techniques work together to put policies into effect to attain policy goals and they also refer implementation can be viewed as a process, an output, and an outcome." In the same way, Meter, Horn, Van Meter, \& Van Horn, (1975) mentioned that "policy implementation incorporates those actions by public and private individuals that are directed at the attainment of objectives set forth in prior policy decisions." On the other hand, Dye, (2012: p.61) explains that "it involves activities to carry out the policies that enacted by the legislative branch and implementation involves activities for the creation of new departments, agencies, bureaus, and so on." Harold D. Lasswell, (1971: p.28) identifies seven stages of policy implementation as intelligence, promotion, prescription, innovation, application, termination, and appraisal. Hill \& Hupe, (2002: p.42) refers policy implementation is partially a political process. DeGroff \& Cargo, (2009: p.4) quoting Paul Berman, (1978: p.4) noted that "in general, policy implementation can be considered the process of carrying out a government decision." Ottoson, J. M., \& Green, (1987: p.354) refers that "the success of an adopted public policy depends on who successfully it is implemented and even the very best policy is of little worth if it has not been implemented successfully."

Pulzl, H. \& Treib, (2007: p.89) mentioned that "distinguished scholars like Van Meter \& Van Horn, (1975) and Sabatier \& Mazmanian, (1980) illustrated top-down model in explaining implementation, while bottom-up scholars like Elmore, (1993: pp 96-124), Lipsky, (1980) emphasized that implementation consist of the everyday problem-solving strategies of street-level bureaucrats." Meter, Horn, Van Meter, \& Van Horn's, (1975) “top-down model comprised of six variables to shape the linkage between policy and performance which includes: (a) policy standards and objectives; (b) resources; (c) intergovernmental communication and enforcement activities; (d) characteristics of implementing agencies; economic, social and political conditions and (e) the disposition of the implementers." Sabatier \& Mazmanian's, (1980: p.22) "top-down approach involved 16 independent variables in the implementation process within 3 categories including (i) the tractability of the problem; (ii) the ability of the statute to structure implementation and (iii) non-statutory variables affecting implementation." On the contrary, Matland,(1995: p.148) quoting Paul Berman, (1978) was assumed that "policy implementation occurs at two levels: (i) macro implementation where the centrally located actors devise a government program, and (ii) micro implementation where local actors react to these plans and develop their own plans and implement them." Goggin et al., (1990: p.15) refers that "further scholars tend to unify the two approaches to provide a hybrid one and argue that policymakers should employ policy instruments based on the structure of target groups."

Moreover, Poister, (2004: p.98) referred that "performance measurement systems can be thought of as both evaluation tools and management systems that are designed to provide 
useful feedback on performance to strengthen decision making and improve program and organizational performance." Similarly, Love, (2004: p.67) categorized "the methods of evaluating implementation as formative evaluation, process evaluation, descriptive evaluation, performance monitoring, and implementation analysis." On the other hands, CDC, US Department of Health, (2012) illustrated that "the evaluation design may also include exploration of differences in implementation in different contexts or for different variations of the policy and identifying the core components of implementation can be challenges, but this step is vital when developing the evaluation questions and measures."

\subsection{Theoretical Framework and Relationships of the Factors Affecting Policy Implementation Performance}

Synthesizing the previous work of prominent scholars on policy implementation theories, deductive theoretical models, the concept of public policy, policy performance, implementation evaluation and policy evaluation, measuring health policy implementation performance demands for finding the relationships of variables with policy implementation performance. Hence in this study, in the following sections tries to briefly review the empirical study of eminent scholars with reference to the identified variables with policy implementation performance for developing a conceptual framework.

\subsubsection{Policy Related Factors and Policy Implementation Performance}

\subsubsection{Clear Goals and Objectives and Policy Implementation Performance}

Clear goals and objectives of any policy are considered as an important determining factor for the successful policy implementation performance. Many of the previous studies on successful policy implementation have described the positive effects of clarity of goals and objectives of public policy on the policy implementation performance. The following section is the short discussion of the earlier studies and findings regarding clear policy goals and objectives and policy implementation performance. Van Meter \& Van Horn, (1975) refers that "the characteristic of nature of the policy that may influence to policy implementation is the degree of conflict or consensus over its goals and objectives." Also, Matland, (1995: p.155) noted that "if in a policy it is not incorporate specific policy goals and objectives it fails to provide realistic yardsticks with which to measure policy outcomes and implementation success is the loyalty to the policy goals and objectives. Policy implementation requires clear policy goals to achieve objectives." Likewise, Berman, (1978) reported; "the clarity of goals, targets, and objectives encourage and fosters prompt implementation." If the goals or objectives of the public policy are not clear, well-defined, well-specified and compatible, it is very likely that the implementers would understand and interpret them in different or wrong ways, and as such, these might lead to unintended consequences regarding policy performance. Edwards, (1980: pp.147-149) stated that "orders to implement a policy must be consistent, clear and accurate in specifying the aims of the decision-makers." Further, Martin Rein, (1983) has put into view and contends that "policy implementation is a matter not only of power but of puzzlement, of men collectively wondering what to do." Similarly, Nakamura \& Smallwood, F., (1980: p.33) quoted that "the lack of specific variable leads to a less focused analysis and clear policy goals and objectives 
are a foundation of effective implementation." Pressman, J. L., \& Wildavsky, (1973: p.xxiv) asserted that "when objectives are not realized, one explanation is the assertion of faulty implementation”. Palumbo, D., \& Harder, (1981: p.29) stated that many recent case studies of implementation failure suggest the confusion over goals is a significant part of the implementation problem. Sabatier \& Mazmanian, (1980: pp.21-22) emphasized sixteen important variables for ensuring effective policy implementation including clear and consistent goals. Therefore, the clarity of policy goals and objectives have a positive effect on policy implementation performance.

\subsubsection{Adequate Budget, Utilization and Autonomy of Financial Power and Policy Implementation Performance}

Several numbers of the preceding studies on successful policy implementation have labeled the positive effects of an adequate budget, utilization and autonomy of financial power on the policy implementation performance. The succeeding section is a discussion of the previous studies and findings concerning adequate budget, utilization, and autonomy of financial power and policy implementation performance. Van Meter \& Van Horn, (1975) reported that "the implementation process would be influenced by the number of resources required for effective implementation of policy." In addition, Sabatier \& Mazmanian, (1980: p.22) identified the key independent variable of the initial allocation of financial resources for successful policy implementation performance. Equally, Edwards, (1980: p.147) mentioned that for effective implementation of policy, it needs resources to serve the communities. Correspondingly, Voradej Chandarasorn, (2005) noted that decentralization of organization, effective budget, and financial management are very important for successful policy implementation. Hence, proper safeguard should also be taken to prevent misuse, underutilization, and overutilization of budgetary allocation. It is believed that decentralization and delegation of financial authority will enhance the capability of the organization to be proactive and innovative. Therefore, required budget, efficient utilization, and autonomy of financial power have a positive effect on policy implementation performance.

2.2.1.3 Adequate Level of Equipment, Health Human Resources, Infrastructure and Policy Implementation Performance

Resources (Health Human Resources, Equipment, Infrastructure) have a positive impact on successful policy implementation. Using adequate equipment and appropriate or sophisticated new technology and innovation helps policy implementation process faster. All policy implementation requires adequate and qualified human resources as well as good infrastructure for service delivery.

Berman, (1978) and Lipsky, (1980) in their separate study emphasized all types of resources, especially the adequate and well-trained street level or micro level implementers. Also, Edwards, (1980: pp.10-12) reported that for effective implementation of policy, it needs resources and well trained, responsible, motivated frontline public employee to serve the communities and beyond these, the administrative leaders are prerequisite behind the political leaders to effectively implement public policy. On the other hand, Dussault \& Dubois, 
(2003) contends that "the lack of appropriate health human resources and policies is responsible in many countries for a chronic imbalance with multifaced effects of health workforces like mismatch, unequal distribution and lack of coordination between human resources management and health policy needs for delivering services." Similarly, Voradej Chandarasorn, (2005) in his management model refers that policy implementation performance depends on personnel and human resources management and adequacy, budget, equipment, and infrastructure. Moreover, Kress, Su, \& Wang, (2016: p.302) in their study found that the performance of the primary health care is hampered by a lack of infrastructure, drugs, equipment and vaccines at the facility level, financial access and poor health providers performance. Furthermore, Lassi et al., (2016: p.1) in a study on low and middle-income countries showed that all the human resources for health interventions implemented individually or combinedly had a positive impact on health policy implementation with reference to maternal health. Therefore, it is assumed that enough equipment, qualified health human resources, and proper infrastructure have a positive effect on the successful implementation of policy.

\subsubsection{Organization Related Factors and Policy Implementation Performance}

\subsubsection{The Inter-Organizational Coordination and Policy Implementation Performance}

Inter-organizational coordination and policy implementation performance have significant relationships regarding successful policy implementation. The subsequent section is a brief description with reference to coordination and policy implementation performance. Pressman, J. L., \& Wildavsky, (1973: p.87-143) in their classic study revealed that coordination among agencies involved is linked with policy formulation and implementation. A large number of agencies working in an implementation process would lead to complexity of joint action, hence, more the implementation delay. The greater the implementation delay the greater the possibility of implementation failure. When many parties are involved in an intervention there must be some contradictory criteria, intra-agency antipathies, differences of opinions, fractions, divisions, antagonistic relationships among participants and stakeholders. These might lead to implementation delay as well as implementation failure. The policy coordination among the policy implementing agencies is essential for implementation success. For example, the complexity of joint actions was one the major causes of the failure of the EDA programs. Laurence et al., (1984: p.491) in their study noted that as the relative importance of coordination increases sequential and reciprocal interdependence and become more attractive that lead to the successful policy implementation. Copeland \& Wexler, (1995: p.63) pointed out that "inter-organizational procedures such as communications, administrative distance, and administrative complexity influence the bureaucratic structure and thereby influence the functional procedures of policy implementation." Peterlin, (2012: p.4) quoting Peters, (1998: p.4) mentioned that "coordination in policy analysis need to ensure that various organization charged with delivering public policy work together and do not produce either redundancy or gaps in services." Similarly, Edward T. Jennings \& Ewalt, (1998: p.417) in a study examines the effect of coordination patterns and administrative arrangement and have found the increased level of coordination that leads to some degree of correlation with the level of performance with five out of ten outcome variables. 
Moreover, Bryson, Crosby, \& Middleton Stone, (2006: p.44) noted that organization that shares information, undertake coordinated initiatives or develop share power arrangement such as collaborations to pool their capabilities to address the challenge and problem that lead the successful implementation of policies. In addition, Bouckaert, Peters, \& Verhoest, (2010) mentioned that government is inherently multi-organizational, and coordination is one of the oldest problem facing the public sector. Government organization providing different services, for the same services coordination became an issue for successful implementation of public policy. Hence, the sound inter-organizational coordination has positive effect on policy implementation performance.

\subsubsection{Management Dynamics and Policy Implementation Performance}

Management dynamics and policy implementation performance have strong relationships with reference to effective policy implementation. The next section is an insight of the relationship between management dynamics and policy implementation performance. The stronger, diligent, enthusiastic, adoption of new technology and optimistic behavior of manager for good management of organization are needed for successful implementation of policy. Giacchino \& Kakabadse, (2003: p.139) in their study found that three decisive factors are responsible for successful policy implementation including political responsibility, the presence of a strong management or team dynamic and the type and level of commitment. At the same time, Meier \& O'Toole, (2003: p.689) refers that "public policies are increasingly implemented in a complex network of organizations and target population and effective action require managers deal with arrays of other actors to procure resources, build support, coproduce results and overcome hindrance to the implementation of policy." On the other hand, Voradej Chandarasorn, (2005) noted in his management model that the main theme is that implementing agency should have a clear organization structure supported by the frontline implementers with desired skills and competency. In addition, Horn \& Thiel, (2014) discussed "the management of implementation and implementing agents, also known as public management for the governance and control, the financial management and the use of management techniques to measure and improve performance for policy implementation." Therefore, various alternatives must be taken into consideration in selecting implementation location through digital management using information and communication technology (ICT) to reach unbounded location and creating facilities for all the citizen. Hence, the good management dynamics together with digital management have a positive effect on policy implementation performance.

\subsubsection{Individual Level Factor and Policy Implementation Performance}

2.2.3.1 The Disposition or Response of Implementers and Policy Implementation Performance

McLaughlin, (1987: p.171) refers that "policy cannot always mandate what matters to the outcomes at the local level and individual beliefs is central to the local response." The disposition of implementers and policy implementation performance is one of the factors that relate to the successful implementation of policy. The implementer's disposition is the acceptance of the actors at the stage of implementation which affects effective implementation. 
The following section is the brief examination of the association between the disposition of implementers and policy implementation performance. Van Meter \& Van Horn, (1975) indicated that "the disposition of implementers may affect their ability and willingness to affect policy in the following ways; implementer's cognition (comprehension or understanding) of the policy, the direction of response toward it (acceptance, neutrality, rejection), and the intensity of response." There might be an intentional tendency by frontline implementers not to comply decisions which passed on to them regarding policy implementation and consequently it might lead to implementation delay and failure. Front-line implementers must have to be accountable for their works. Imparting proper training, manual, monitoring, supervision, adequate budget, equipment, and technology to the frontline implementers can vibrate implementation process and guard against the mode of unintentional non-compliance. It requires establishing good technology and training to control the behavior of the street-level bureaucrats like the closed-circuit camera. So, compliance behavior is very important for policy implementation. In the same way, Berman, (1978: p.25) in the study of macro and micro-implementation reported that "in micro-implementation, the local organization has to devise and carry out their own internal policies." Accordingly, Edwards, (1980: p.10) stated that "the first requirement for effective implementation is that those responsible for carrying out a decision must know what they are supposed to do and identified four interacting and simultaneously operating factors including communication, resources, dispositions and bureaucratic structure." Meanwhile, Najam, (1995: p.5) reviews that "if responsible for carrying out are unwilling or unable to do so little will happen, and responsibility or disposition is considered to be a critical variable to effective policy implementation." Hence, the positive attitude and responsibility for policy compliance of the implementers have a significant effect on policy implementation performance.

\subsubsection{Local Level Support and Policy Implementation Performance}

2.2.4.1 The Micro Level Support from Local Stakeholders and Policy Implementation Performance

According to McLaughlin, (1987: p.171) successful implementation needs a planned and steadiness of pressure and support. Many previous studies on policy implementation refer the relationship between the micro level support from stakeholders and policy implementation performance. The following section is attempted to review the work of prominent scholars. The prominent scholar Pressman, J. L., \& Wildavsky, (1973) describe in their book 'Implementation' that implementation process is a system of pressures and counter-pressures. Pressman, J. L., \& Wildavsky, also (1973: p.102) mentioned that "even minor disagreements between just a few actors can cause delays and a vicious cycle of delay, fair of ultimate failure or high salvage costs, withdrawal of previous commitments and increased anxiety can cause implementation failure." The Economic Development Administration (EDA) is a perfect example of pressure politics. Nassera Touati et al., (2007: p.98) reported referring Sabatier \& Mazmanian's, (1980: p.21) that "general analytical framework, which identifies three types of variables that affect policy implementation performance and among the variables the 'non-statutory' variables related to implementation context (e.g. socio-economic condition, support from interest group and stakeholders and 
stakeholders 'leadership) affect implementation performance." Similarly, USAID, (2007) conducted a policy reform report and mentioned that "stakeholders must participate in the determination of feasible policy options, appropriate time frames and implementation approaches for successful policy implementation.” Equally, Voradej Chandarasorn, (2005) in his Political model of policy implementation mentioned four independent variables including the level of support from different stakeholders are important for successful policy implementation. Franke \& Guidero, (2012: p.8) on the other hand, in their study, describes that the effective and sustained engagement and support of stakeholder require in the implementation process at every stage for effective and successful implementation.

\subsection{Conceptual Framework, Research Hypotheses and Models of the Study}

The conceptual framework of the study has been established from Allison's, (1971) Essence of Decision, Pressman, J. L., \& Wildavsky's, (1973) Implementation, Van Meter \& Van Horn, (1975), Sabatier \& Mazmanian, (1980), Bardach's, (1977) Implementation Game, Weimer \& Vining's mechanism of policy implementation model, Michael Lipsky's street-level bureaucracy model, down-ward puzzlement model of Martin Rein's, organizational model of Richard Elmore, Edward's administrative influence model, Paul A. Sabatier's advocacy coalition framework, Voradej Chandarasorn's, (2005) five models and other theories and models of policy implementations and the variables associated with the models can distinctively figure out the success or failure of policy implementation. One main dependent variable "health policy implementation performance in primary health care in Bangladesh" has been identified with the following independent variables that divided into four groups and four working models and seven hypotheses.

\subsubsection{Research Hypotheses}

H1: The clearer the goals and objectives, the more possibilities of successful implementation of the policy in primary health care in Bangladesh.

$\mathrm{H} 2$ : The adequate budget and effective utilization and autonomy of financial power, would have the chance of implementation success in primary health care in Bangladesh.

H3: The more the adequate level of equipment, health human resources, and infrastructure, the more possibility of the policy implementation success in primary health care in Bangladesh.

H4: The more inter-organizational cooperation and coordination the more chance of successful implementation of health policy in primary health care.

H5: The good management can lead the policy implementation success in primary health care in Bangladesh.

H6: The positive disposition or response of implementers would lead to policy implementation success.

H7: Micro-level support from local stakeholders will have a positive effect to health policy implementation performance in primary health care in Bangladesh. 


\section{Independent Variables}

\section{Dependent Variable}

\section{Policy Related Factors}

1. Clarity of Goals and Objectives

2. Adequate Budget and Financial Autonomy

3. Resources (Human, Infrastructure and Equipment)

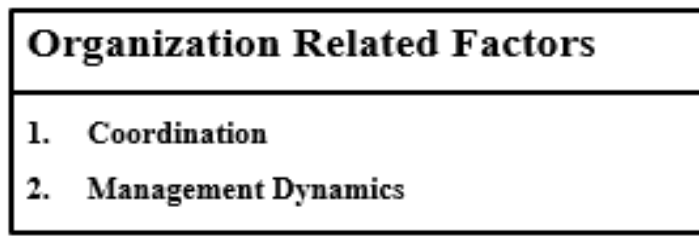

\begin{tabular}{|l|}
\hline Individual Level Factors \\
\hline 1. Implementers' Disposition \\
\hline
\end{tabular}

\section{Local Level Support}

1. Micro Level Support of Stakeholders

Figure 2.1. Development of Conceptual framework

\subsubsection{Model Specification}

Model-1: HPIPPHC $=\beta_{0}+\mathrm{COGAO} \beta_{1}+\mathrm{ABFA} \beta_{2}+\mathrm{REHI} \beta_{3}+\varepsilon_{\mathrm{i}}$

Model-2: HPIPPHC $=\beta_{0}+\mathrm{COGAO} \beta_{1}+\mathrm{ABFA} \beta_{2}+\mathrm{REHI} \beta_{3}+\mathrm{COORD} \beta_{4}+\mathrm{MD} \beta_{5}+\varepsilon_{\mathrm{i}}$

Model-3: $\mathrm{HPIPPHC}=\beta_{0}+\mathrm{COGAO} \beta_{1}+\mathrm{ABFA} \beta_{2}+\mathrm{REHI} \beta_{3}+\mathrm{COORD} \beta_{4}+\mathrm{MD} \beta_{5}+\mathrm{ID} \beta_{6}+\varepsilon_{\mathrm{i}}$

Model-4:

$\mathrm{HPIPPHC}=\beta_{0}+\mathrm{COGAO} \beta_{1}+\mathrm{ABFA} \beta_{2}+\mathrm{REHI} \beta_{3}+\mathrm{COORD} \beta_{4}+\mathrm{MD} \beta_{5}+\operatorname{ID} \beta_{6}+\mathrm{MLSS} \beta_{7}+\varepsilon_{\mathrm{i}}$

Where,

HPIPPHC $=$ Health Policy Implementation Performance in Primary Health Care

COGAO $=$ Clarity of Goals and Objectives

$\mathrm{ABFA}=$ Adequate Budget and Financial Autonomy

REHI $=$ Resources (Equipment, Human Resources, Infrastructure)

COORD $=$ Coordination

$\mathrm{MD}=$ Management Dynamics

$\mathrm{ID}=$ Implementer's Disposition 
MLSLS= Micro Level Support from Local Stakeholders

$\varepsilon_{\mathrm{i}}=$ Refers to a random error term that characterises the influence of other variables not contained within the model.

$\beta:=\beta_{0}$ is the statistical symbol indicates the constant or intercept whereas, $\beta$ with other independent variables designates the regression beta coefficient for the corresponding independent variables.

\section{Materials and Methods}

\subsection{Research Design}

The study has been conducted using quantitative methods using primary data. Feedbacks to the survey, questionnaires were designed on a six-point Likert-type scale ( $6=$ Very High, 5=High, 4=Slightly High, 3=Slightly Low, 2=Low, 1=Very Low). There is 424 sub-districts level health center in Bangladesh. The whole population of the sub-districts level health facilities was employed to collect the perceived opinion of UH\&FPOs (Upazilla Health \& Family Planning Officers). So, the unit of analysis was the organization of Upazila Health Complex and data has been collected from the UH\&FPOs, the administrative head at the sub-district level health centers. Based on the primary data, descriptive statistics, ANOVA, factor analysis, Pearson correlation matrix and hierarchical multiple regression were used to measure the indicators developed under the factors influencing health policy implementation performance in primary health care. The structured self-administered questionnaire and multi-methods for data collection were used as such postal and electronic mail survey, and direct communication for the survey. Thus, the target population was 424 Upazila Health Centers (UHC) and the total respondents of 424 were one from each sub-district. For this study, total 240 respondents were responded. The response rate was $56.60 \%$.

\subsection{Measuring Policy Implementation Performance in Primary Care}

Primary health care services in Bangladesh have been focused in terms of eight features as a countersign to the announcement in the international conference on primary health care held at Alma Ata in 1978. The primary health care features include adequate and safe water and sanitation, health education, nutrition, immunization, maternal and child health, prevention, and control of endemic diseases, treatment of common ailments and injuries and provision of essential drugs. Ministry of Health and Family Welfare, (2012) stated that the current primary health care approach already in place, includes (a) child health care, safe motherhood, family planning, menstrual regulation (MR), post-abortion care, and management of sexually transmitted infections; (b) communicable diseases (including TB, Malaria, others); (c) emerging non-communicable diseases (diabetes, mental health, cardiovascular diseases); and (d) limited curative care and behavioral change communication (BCC).

The dependent variable, health policy implementation performance in primary health care, was measured based on the perceived opinion regarding implementation performance by the Upazila health and family planning officer from 424 sub-district level health facilities in Bangladesh. Bhuyan, A., Jorgensen, A., \& Sharma, (2010: p.5) has dealt "in designing and 
measuring the framework for health policy implementation assessment and suggested seven dimensions that influence policy implementation including (1) the policy, its formulation, and dissemination; (2) social, political, and economic context; (3) leadership for policy implementation; (4) stakeholder's involvement in policy implementation; (5) implementation planning and resource mobilization; (6) operations and services and (7) feedback on progress and results." On the other hand, Dunn, (1981: pp.342-343) has recommended "six criteria for evaluating policy performance, including effectiveness, efficiency, adequacy, equity, responsiveness, and appropriateness.". Poister, (2004: p.99), has mentioned seven types of performance measures together with resources, outputs, productivity, efficiency, service quality, outcomes, cost-effectiveness and customer satisfaction. Based on World Banks's framework the US Agency for International Development, USAID, (2007) developed criteria for health system performance assessment includes equity, access, quality, efficiency, and sustainability.

Similarly, D. H. Peters, Tran, \& Adam, (2013) in their WHO's practical guide to implementation research in health refers that to evaluate the success or failure of implementation as implementation outcome variables which serves as indicators of how well a given implementation is actually working and the outcome variables that mostly reflects by the perception among stakeholders (e.g. policy makers, providers, consumers, managers,) are-acceptability, appropriateness, adoption, feasibility, fidelity, cost, coverage and sustainability. Likewise, Economist Intelligence Unit, (2010) in their study on enabling policy implementation reported that they used perceived opinion regarding how effective the organizations at implementing the mandated policy (e.g. very effective, somewhat effective). The study was measured the perceived policy implementation performance, success or failure in primary health care using the policy implementation performance evaluation criteria of equity, quality of primary health services, access to health care, availability, appropriateness, and satisfaction. To measure the health policy implementation performance the criteria of equity, quality of services, accessibility, availability of services, appropriateness, and satisfaction have been used to ask the respondents (the UH\&FPO) of their perceived opinion regarding policy implementation performance in primary health care in Bangladesh. To get the perceived opinion of the respondents (UH\&FPO) regarding the understanding of health policy implementation performance in primary health care in Bangladesh on each of the dependent and independent variables and their corresponding indicators, a six-point Likert scale questionnaire have been constructed that symbolizes (6=Very High, 5=High, 4=Slightly High, 3=Slightly Low, 2=Low, 1=Very Low).

\subsection{Reliability Analysis}

Prior to the conducting of the survey 50 samples were collected from the total population of UH\&FPOs for reliability and validity of the questionnaire items scale construction. Reliability and factor analysis are statistical methods of data reduction. The Cronbach Alpha values of all the variables were found within the most preferred and excellent level and above the suggested level of .70 (suggested by DeVellis, 2003 in Pallant, 2010: p.97). Hence, the scales of items constructed in the questionnaires was highly reliable (see Table 3.1). 


\section{Macrothink}

Journal of Public Administration and Governance

ISSN 2161-7104

2018, Vol. 8, No. 1

Table 3.1. Summary Results of Reliability Analysis of the Scales for Internal Consistency of Variables $(\mathrm{N}=50)$

\begin{tabular}{|c|c|c|c|c|}
\hline $\begin{array}{l}\text { Sl. } \\
\text { Number }\end{array}$ & Variables & $\begin{array}{l}\text { Average } \\
\text { Inter-Item } \\
\text { Correlation }\end{array}$ & $\begin{array}{l}\text { Range of } \\
\text { Inter-Item } \\
\text { correlation }\end{array}$ & $\begin{array}{l}\text { Cronbach } \\
\text { Alpha }(\alpha)\end{array}$ \\
\hline 01 & Clarity of Goals and objectives & .444 & .548 & .846 \\
\hline 02 & $\begin{array}{l}\text { Adequate budget and financial } \\
\text { autonomy }\end{array}$ & 645 & .375 & .926 \\
\hline 03 & $\begin{array}{l}\text { Resources (Human, } \\
\text { Infrastructure and Equipment) }\end{array}$ & .424 & .795 & .879 \\
\hline 04 & Coordination & .494 & .530 & .872 \\
\hline 05 & Management Dynamics & .504 & 687 & .896 \\
\hline 06 & Implementers' Disposition & .581 & .500 & .924 \\
\hline 07 & $\begin{array}{l}\text { Micro level support of } \\
\text { stakeholders }\end{array}$ & .688 & .389 & .939 \\
\hline 08 & $\begin{array}{l}\text { Overall perceived level of } \\
\text { health policy implementation } \\
\text { performance in primary health } \\
\text { care }\end{array}$ & .399 & .652 & .841 \\
\hline
\end{tabular}

\subsection{Factor Analysis and Content Validity by Experts}

For this study, in the pre-test subjected to the Factor Analysis, Reliability analysis and Content validity by the experts were done. For the content validity of the questionnaire, expert opinion using the Index of Item-Objective Congruence (IOC) developed by Rovinelli \& Hambleton, (1977) were taken from four content experts from both Thailand and Bangladesh. For factor analysis principal component analysis was employed. Two statistical tests were done for factorability of intercorrelation matrix including (i) Kaiser-Meyer Olkin (KMO) measures for sampling adequacy; and (ii) Bartlett's test of Sphericity. Meyers, Gamst, \& Guarino, (2013: p.691) stated that for Kaiser-Meyer Olkin (KMO) measures for sampling adequacy, a value of 0.70 or above is considered adequate that the data are suitable for factor analysis (see Table 3.2). Meyers, Gamst, \& Guarino, (2013: p.691) stated that Bartlett's test of Sphericity investigates a test of the null hypothesis that none of the variables are significantly correlated. This test was significant at the $\mathrm{p}<.0 .05$ level for all factors (see Table 3.2). The rotated loadings of all the items being loaded greater than .50 that confirmed the effectiveness of the observed items for factor analysis. Hence, all the items in the reliability analysis and factor analysis were found valid and reliable in the scale construction. 


\section{Ml Macrothink}

Table 3.2. Summary Results of Factor Analysis

\begin{tabular}{|c|c|c|c|}
\hline $\begin{array}{l}\text { Sl. } \\
\text { No }\end{array}$ & Variables & $\begin{array}{l}\text { Kaiser-Meyer } \\
\text { Olkin (KMO) }\end{array}$ & $\begin{array}{l}\text { Bartlett's test of Sphericity } \\
\text { \& Variance Explained }\end{array}$ \\
\hline 1 & $\begin{array}{l}\text { Clarity of Goals and objectives ( } 7 \\
\text { items) }\end{array}$ & .740 & $\begin{array}{l}\text { Chi-Square }\left(\chi^{2}\right)=153.311 \mathrm{p}<.0 .05 \text {, } \\
\text { Variance explained 53.012\% }\end{array}$ \\
\hline 2 & $\begin{array}{l}\text { Adequate budget and financial } \\
\text { autonomy ( } 7 \text { items) }\end{array}$ & .861 & $\begin{array}{c}\text { Chi-Square }\left(\chi^{2}\right)=276.708 \\
p<.0 .05 \\
\text { Variance explained } 69.738 \%\end{array}$ \\
\hline 3 & $\begin{array}{l}\text { Resources (Human, Infrastructure } \\
\text { and Equipment) (10 items) }\end{array}$ & .838 & $\begin{array}{c}\text { Chi-Square }\left(\chi^{2}\right)=304.877 \\
p<.0 .05 \\
\text { Variance explained } 69.439 \%\end{array}$ \\
\hline 4 & Coordination (7 items) & .770 & $\begin{array}{c}\text { Chi-Square }\left(\chi^{2}\right)=169.199 \\
\text { p }<.0 .05\end{array}$ \\
\hline 5 & Management Dynamics (9 items) & .796 & $\begin{array}{c}\text { Variance explained } 56.999 \% \\
\text { Chi-Square }\left(\chi^{2}\right)=280.426 \\
\text { p }<.0 .05\end{array}$ \\
\hline 6 & $\begin{array}{l}\text { Implementers' Disposition (9 } \\
\text { items) }\end{array}$ & .822 & $\begin{array}{c}\text { Variance explained } 72.989 \% \\
\text { Chi-Square }\left(\chi^{2}\right)=337.869 \\
p<.0 .05 \\
\text { Variance explained } 74.867 \%\end{array}$ \\
\hline 7 & $\begin{array}{l}\text { Micro level support of } \\
\text { stakeholders ( } 7 \text { items) }\end{array}$ & .859 & $\begin{array}{c}\text { Chi-Square }\left(\chi^{2}\right)=316.217 \\
\quad p<.0 .05\end{array}$ \\
\hline 8 & $\begin{array}{l}\text { Overall perceived level of health } \\
\text { policy implementation } \\
\text { performance in primary health } \\
\text { care }(8 \text { items })\end{array}$ & .728 & $\begin{array}{c}\text { Variance explained } 73.286 \% \\
\text { Chi-Square }\left(\chi^{2}\right)=189.282 \\
p<.0 .05 \\
\text { Variance explained } 68.460 \%\end{array}$ \\
\hline
\end{tabular}

\section{Results of the Study}

\subsection{Descriptive Statistics}

Table 4.1 represents the descriptive statistics of the dependent variable and seven independent variables. Table 4.1 discloses the descriptive statistics of the dependent variable that the respondents were given their opinion for high performance of the health policy implementation performance with the mean score of the variable 4.0190. The respondents were given their perceived opinion on a high understanding of the independent variables 'Clarity of Goals and objectives (COGAO)' and 'Implementers' Disposition (ID)' with a mean score of 4.0145 and 4.0783 respectively (see Table 4.1). For the rest of the independent variables, it was slightly high with the mean scores of above 3.00 to below 4.00 (see Table 4.1). The standard deviations of all the variables were found low. Furthermore, the Skewness and Kurtosis of the of the dependent and independent variables were found within the array of plus one to minus one which established the assumption of normal distribution of data (see Table 4.1). 
Table 4.1. Descriptive Statistics of the Dependent and Independent Variables

\begin{tabular}{|c|c|c|c|c|c|c|c|c|}
\hline Independent Variables & Min. & Max & Mean & SD. & \multicolumn{2}{|c|}{ Skewness } & \multicolumn{2}{|c|}{ Kurtosis } \\
\hline $\begin{array}{l}\text { Clarity of Goals and objectives } \\
\text { (COGAO) }\end{array}$ & 1.71 & 5.71 & 4.0145 & .71885 & -.352 & .158 & -.054 & .315 \\
\hline $\begin{array}{l}\text { Adequate budget and financial } \\
\text { autonomy (ABFA) }\end{array}$ & 1.29 & 5.86 & 3.2833 & .86177 & .183 & .158 & -.113 & .315 \\
\hline $\begin{array}{l}\text { Resources (Human, Infrastructure and } \\
\text { Equipment) (REHI) }\end{array}$ & 1.40 & 5.20 & 3.1481 & .76405 & .263 & .158 & -.248 & .315 \\
\hline Coordination (COORD) & 1.71 & 6.00 & 3.8602 & .79108 & -.187 & .158 & -.220 & .315 \\
\hline Management Dynamics (MD) & 1.89 & 5.56 & 3.8106 & .73977 & -.143 & .158 & -.296 & .315 \\
\hline Implementers' Disposition (ID) & 1.44 & 5.89 & 4.0783 & .76453 & -.513 & .158 & .137 & .315 \\
\hline $\begin{array}{l}\text { Micro level support from local } \\
\text { stakeholders (MLSLS) }\end{array}$ & 1.00 & 5.57 & 3.2586 & .96678 & -.054 & .158 & -.625 & .315 \\
\hline $\begin{array}{l}\text { Overall perceived opinion of health } \\
\text { policy implementation performance in } \\
\text { primary health care (HPIPPHC) }\end{array}$ & 2.00 & 5.75 & 4.0190 & 68844 & -.127 & .158 & -.168 & .315 \\
\hline
\end{tabular}

\subsection{Data Management and Checking the Assumptions of Multiple Regression}

The data have been checked for the multivariate assumptions of normality, linearity, multicollinearity, homoscedasticity, independence of error and outliers. Normality was checked by the histogram, normal curve overlay, skewness and kurtosis, normal probability plot (P-P), histogram and scatterplot of regression residuals and Kolmogorov-Smirnov test and among them, only Kolmogorov-Smirnov test was not satisfied for the large set of data. Pallant, (2010: p.57) refers quoting Tabachnick \& Fidell, (2007: p.80) that "with a reasonably larger sample of 200 plus the risk is reduced and relaxed as a normal distribution. Field, (2009: p.139) also suggested seeing the value of skewness and kurtosis instead of calculating only significance. For this study, the skewness and kurtosis results for all variables were found within the normal limit of plus one to minus one. For linearity test, the scatter plots of the dependent and independent variables were checked and found cigar shape as suggested by Pallant, (2010: pp.129-131).

Moreover, Table 4.2 presents the correlation matrix, that confirmed there was no correlation coefficient above .70 and below .30 that confirmed that there was no multicollinearity (Pallant, (2010: p.158). Similarly, all the tolerance values were above .10 and all VIF statistics were below 10 the cut-off edge for settling the absence of multicollinearity assumption of multiple regression (see Table 3.6, 3.7, 3.8 and 3.9). For this study, ANOVA for the test of equal variance (Levene's test) was used and found insignificant for all variables that confirmed the non-violation of the assumption of homoscedasticity. Durbin-Watson Statistics was found 1.729 that determined the assumption of the non-violation of independence of error. Outliers were checked through scatterplot of standardized regression residual and it looked like all the cases were within the limit of 3.3 or less than -3.3 suggested by Tabachnick \& Fidell, (2007: p.125).

\subsection{Correlation Analysis}

Table 4.2 represents the correlation matrix of dependent and independent variables. Table 4.2, also confirmed that all the correlation coefficient cascading under the range of .38 to .69 that characterized medium to strong positive correlation among the group of variables with 


\section{Macrothink}

1-tailed single directional at the $\mathrm{p}<0.01$ level of significant (Cohen, 1988: pp.79-81). Hence, all the independent variables were highly positively correlated with the health policy implementation performance in primary health care in Bangladesh.

Table 4.2. Correlation Matrix of Dependent and Independent Variables

\begin{tabular}{|c|c|c|c|c|c|c|c|c|}
\hline Variables & $\begin{array}{l}\mathrm{COG} \\
\mathrm{AO}\end{array}$ & $\begin{array}{l}\mathrm{ABF} \\
\mathrm{A}\end{array}$ & REHI & $\begin{array}{l}\text { COOR } \\
\text { D }\end{array}$ & MD & ID & MLSLS & HPIPPHC \\
\hline COGAO & 1 & $.517 *$ & $.382^{*}$ & $.492 * *$ & $.534 *$ & $.475^{*}$ & $.472 * *$ & $.606 * *$ \\
\hline Sig.(1-taile & & * & $*$ & .000 & $*$ & * & .000 & .000 \\
\hline & & .000 & .000 & & .000 & .000 & & \\
\hline ABFA & & 1 & $.613^{*}$ & $.567 * *$ & $.550 *$ & $.479 *$ & $.449 * *$ & $.522 * *$ \\
\hline Sig.(1-taile & & & $\begin{array}{c}* \\
000\end{array}$ & .000 & $\begin{array}{c}* \\
000\end{array}$ & * & .000 & .000 \\
\hline REHI & & & .000 & $640 * *$ & .000 & $440 *$ & $490 * *$ & $519 * *$ \\
\hline $\begin{array}{l}\text { Sig.(1-taile } \\
\text { d) }\end{array}$ & & & & .000 & * & $*$ & .000 & .000 \\
\hline COORD & & & & 1 & $.640 *$ & $.564 *$ & $.477 * *$ & $622 * *$ \\
\hline Sig.(1-taile & & & & & $*$ & $*$ & .000 & .000 \\
\hline d) & & & & & .000 & .000 & & \\
\hline MD & & & & & 1 & $.699 *$ & $.547 * *$ & $.694 * *$ \\
\hline $\begin{array}{l}\text { Sig.(1-taile } \\
\text { d) }\end{array}$ & & & & & & $\begin{array}{c}* \\
.000\end{array}$ & .000 & .000 \\
\hline ID & & & & & & 1 & $.394 * *$ & $.695 * *$ \\
\hline $\begin{array}{l}\text { Sig.(1-taile } \\
\text { d) }\end{array}$ & & & & & & & .000 & .000 \\
\hline MLSLS & & & & & & & 1 & $.460 * *$ \\
\hline $\begin{array}{l}\text { Sig.(1-taile } \\
\text { d) }\end{array}$ & & & & & & & & .000 \\
\hline HPIPPHC & $.606 * *$ & $.522 *$ & $.519 *$ & $.622 * *$ & $.694 *$ & $.695 *$ & $.460 * *$ & 1 \\
\hline $\begin{array}{l}\text { Sig.(1-taile } \\
\text { d) }\end{array}$ & .000 & $\begin{array}{c}* \\
.000 \\
\end{array}$ & $\begin{array}{c}* \\
.000 \\
\end{array}$ & .000 & $\begin{array}{c}* \\
.000 \\
\end{array}$ & $\begin{array}{c}* \\
.000 \\
\end{array}$ & .000 & \\
\hline
\end{tabular}

Pearson $* *$ Correlation is significant at the 0.01 level (1-tailed), List wise $\mathrm{N}=237$

\subsection{Hypothesis Testing for the Study}

Resulting in the responses from the survey questionnaires, the proposed seven hypotheses were tested. For hypothesis testing the Pearson correlation matrix, ANOVA (if F-calculate is greater than F-alpha, we can reject the null hypothesis significantly) and the p-value method of hierarchical multiple regression analysis (If the p-value is less than alpha, we can reject the null hypothesis significantly) were used. Four hypotheses were fulfilled and accepted out of seven hypotheses (see Table 4.3). 


\section{$\triangle 1$ Macrothink}

Journal of Public Administration and Governance

ISSN 2161-7104

2018, Vol. 8, No. 1

Table 4.3. Table Summary of Hypothesis testing, Dependent Variable Health Policy Implementation Performance in Primary Health Care

\begin{tabular}{|c|c|c|c|}
\hline Hypothesis & Explanatory Variables & $\begin{array}{l}\text { Directional } \\
\text { Relationship } \\
\text { (sign) }\end{array}$ & $\begin{array}{c}\text { Decision } \\
\text { (Accept/reject) }\end{array}$ \\
\hline $\mathrm{H} 1$ & $\begin{array}{l}\text { Clarity of Goals and } \\
\text { Objectives (COGAO) }\end{array}$ & + & $\begin{array}{l}\text { Fully accepted using Pearson } \\
\text { correlation, ANOVA and } \\
\text { Regression coefficient }\end{array}$ \\
\hline $\mathrm{H} 2$ & $\begin{array}{l}\text { Adequate Budget and } \\
\text { Financial Autonomy } \\
\text { (ABFA) }\end{array}$ & + & $\begin{array}{l}\text { Partially fulfilled by using } \\
\text { Pearson correlation and } \\
\text { ANOVA }\end{array}$ \\
\hline $\mathrm{H} 3$ & $\begin{array}{l}\text { Resources (Equipment, } \\
\text { Human Resources, } \\
\text { Infrastructure) (REHI) }\end{array}$ & + & $\begin{array}{l}\text { Partially fulfilled by using } \\
\text { Pearson correlation and } \\
\text { ANOVA }\end{array}$ \\
\hline $\mathrm{H} 4$ & Coordination (COORD) & + & $\begin{array}{l}\text { Fully accepted using Pearson } \\
\text { correlation, ANOVA and } \\
\text { Regression coefficient }\end{array}$ \\
\hline H5 & $\begin{array}{l}\text { Management Dynamics } \\
\text { (MD) }\end{array}$ & + & $\begin{array}{l}\text { Fully accepted using Pearson } \\
\text { correlation, ANOVA and } \\
\text { Regression coefficient }\end{array}$ \\
\hline H6 & $\begin{array}{l}\text { Implementer's Disposition } \\
\text { (ID) }\end{array}$ & + & $\begin{array}{l}\text { Fully accepted using Pearson } \\
\text { correlation, ANOVA and } \\
\text { Regression coefficient }\end{array}$ \\
\hline $\mathrm{H} 7$ & $\begin{array}{l}\text { Micro Level Support from } \\
\text { Local Stakeholders } \\
\text { (MLSLS) }\end{array}$ & + & $\begin{array}{l}\text { Partially fulfilled by using } \\
\text { Pearson correlation and } \\
\text { ANOVA }\end{array}$ \\
\hline
\end{tabular}

\subsection{Multivariate Analysis}

4.5.1 Relationships of the Policy Related Factors and Policy Implementation Performance in Primary Health Care in Bangladesh

The results of model-1 depict that the three policy-related factors can influence the levels of policy implementation performance in primary health care (HPIPPHC). The $\mathrm{R}^{2}$ of the model-1 was found .481 which implies that it can explain $48 \%$ of the variance in the level of policy implementation performance in primary health care (HPIPPHC). All the three variables had positive significant relationship with the levels of policy implementation performance in primary health care (HPIPPHC) in model-1 $\left(\beta=.437^{* *}\right.$ at 0.01 level for COGAO, $\beta=.125^{*}$ at 0.05 level for ABFA and $\beta=.281^{* *}$ at 0.01 level for REHI) and from the ANOVA table the F=72.905 at 0.01level (see Table 4.4). But in the final combined model-4 shows that only the variable Clarity of Goals and Objectives (COGAO) had a unique significant positive contribution to the relationship with policy implementation performance in primary health care (HPIPPHC) $\left(\beta=.238^{* *}\right.$ at 0.01 level for COGAO) and two other policy level variables (ABFA and REHI) had positive but non-significant unique contribution for the relationships (see Table 4.7). The result indicates that the health administrators at the sub-district level health facilities in Bangladesh perceived that for successfully implementation of health policy implementation in primary care depends on the clarity of policy objectives and goals not depends on budget and resources.

Moreover, the $\mathrm{R}^{2}$ gradually increased with the addition of a group of variables in the model 
except for the final addition of one variable (MLSLS= Micro Level Support from Local Stakeholders) in model-4 as such .481, 597, .646 and .647. Hence, the final model-4 can explain combinedly $65 \%$ of the variance in the level of policy implementation performance in primary health care (HPIPPHC) (see Table 4.7).

Table 4.4. Hierarchical Multiple Regression Analysis Results for Model 1

\begin{tabular}{lllllll}
\hline $\begin{array}{l}\text { Independent } \\
\text { Variables }\end{array}$ & $\begin{array}{l}\text { Unstandardized } \\
\text { Coefficient } \\
\text { B }\end{array}$ & $\begin{array}{l}\text { Standardized } \\
\text { Coefficient } \\
\text { Beta }\end{array}$ & $\mathrm{t}$ & Sig. & \multicolumn{2}{c}{ Collinearity Statistics } \\
& 1.221 & & & Tolerance & VIF \\
\hline Constant & .416 & $.437^{*} *$ & 7.937 & 0.000 & & \\
COGAO & .101 & $.125^{*}$ & 1.952 & 0.050 & .725 & 1.379 \\
ABFA & .1053 & $.281^{* *}$ & 4.728 & 0.000 & .621 & 1.851 \\
REHI & .253 & & & & .610 \\
\hline
\end{tabular}

$\mathrm{N}=240 ; *_{\mathrm{p}}<0.05, * * \mathrm{p}<0.01 ; \mathrm{R}^{2}=.481 ;$ Adjusted $\mathrm{R}^{2}=.474 ; \Delta \mathrm{R}^{2}$ (Change) $=.481 ; \mathrm{F}=72.905$ at 0.01 level; Durbin-Watson Statistics $=1.729$ and dependent variable: HPIPPHC

4.5.2 Relationships of the Organization Level Factors and Policy Implementation Performance in Primary Health Care in Bangladesh

The results of model-2 portrays that the two organizational related factors can influence the levels of policy implementation performance in primary health care (HPIPPHC). The $\mathrm{R}^{2}$ of the model-2 was found .597 that means it can explain about $60 \%$ of the variance in the level of policy implementation performance in primary health care (HPIPPHC). Two variables from level 2 had a positive significant relationship with the levels of policy implementation performance in primary health care (HPIPPHC) in model-2 $\left(\beta=.208^{* *}\right.$ at 0.01 level for COORD and $\beta=.379 * *$ at 0.01 level for MD) and from the ANOVA table the $\mathrm{F}=69.401$ at 0.01level (see Table 4.5). In the final combined model-4 displays that both the organizational level factors $(\beta=.142 *$ at 0.05 level for COORD and $\beta=.194 * *$ at 0.01 level for MD) had a unique statistically significant positive contribution for the relationship with policy implementation performance in primary health care (HPIPPHC) (see Table 4.7).

For the addition of two variables in the model- 2 an additional $12 \%$ of the variance can explain in the policy implementation performance after controlling COGAO, ABFA, and REHI, $\Delta \mathrm{R}^{2}$ $($ Change $)=.116, \mathrm{~F}$ change $(2,234)=33.777, \mathrm{p}<0.01$. Hence, the final model -4 can explain combinedly $65 \%$ of the variance in the level of policy implementation performance in primary health care (HPIPPHC) (see Table 4.7).

Table 4.5. Hierarchical Multiple Regression Analysis Results for Model 2

\begin{tabular}{lllllll}
\hline $\begin{array}{l}\text { Independent } \\
\text { Variables }\end{array}$ & $\begin{array}{l}\text { Unstandardized } \\
\text { Coefficient } \\
\text { B }\end{array}$ & $\begin{array}{l}\text { Standardized } \\
\text { Coefficient } \\
\text { Beta }\end{array}$ & $\mathrm{t}$ & & & \multicolumn{2}{l}{ Sig. } & \multicolumn{2}{c}{ Collinearity Statistics } \\
& Tolerance & VIF \\
\hline Constant & .785 & $.267 * *$ & 4.371 & .000 & & \\
COGAO & .255 & .045 & .048 & .000 & .615 & 1.627 \\
ABFA & .036 & .025 & .409 & .432 & .523 & 1.913 \\
REHI & .023 & $.208 * *$ & 3.351 & .001 & .450 & 2.220 \\
COORD & .179 & $.379 * *$ & 6.131 & .000 & .450 & 2.238 \\
MD & .349 & & & & \\
\hline
\end{tabular}




\section{MlMacrothink}

Journal of Public Administration and Governance ISSN 2161-7104 2018, Vol. 8, No. 1

$\mathrm{N}=240 ; * \mathrm{p}<0.05, * * \mathrm{p}<0.01 ; \mathrm{R}^{2}=.597 ;$ Adjusted $\mathrm{R}^{2}=.589 ; \Delta \mathrm{R}^{2}$ (Change)=.116; $\mathrm{F}=69.404$ at 0.01 level; Durbin-Watson Statistics $=1.729$ and dependent variable: HPIPPHC

4.5.3 Relationships of the Individual Level Factor and Policy Implementation Performance in Primary Health Care in Bangladesh

The results of model-3 depicts that the one individual level variable Implementer's Disposition (ID) factors can influence the levels of policy implementation performance in primary health care (HPIPPHC). The $\mathrm{R}^{2}$ of the model-3 was found .646 that means it can explain $65 \%$ of the variance in the level of policy implementation performance in primary health care (HPIPPHC). The individual level variable Implementer's Disposition (ID) from level 3 had positive significant relationship with the levels of policy implementation performance in primary health care (HPIPPHC) in model-3 $\left(\beta=.328^{* *}\right.$ at 0.01 level for Implementer's Disposition (ID)) and from the ANOVA table the F=71.016 at 0.01level (see Table 4.6). In the final combined model-4 displays that the individual level variable Implementer's Disposition (ID) $(\beta=.329 * *$ at 0.01 level for Implementer's Disposition (ID)) had a unique statistically significant positive contribution for the relationship with policy implementation performance in primary health care (HPIPPHC) (see Table 4.7).

For the addition of individual-level variable Implementer's Disposition (ID) in the model-3, an additional $5 \%$ of the variance can explain in the policy implementation performance after controlling COGAO, ABFA, REHI, COORD and MD, $\Delta \mathrm{R}^{2}$ (Change) $=.049$, $\mathrm{F}$ change $(1,233)$ $=32.444, \mathrm{p}<0.01$. Hence, the final model -4 can explain combinedly $65 \%$ of the variance in the level of policy implementation performance in primary health care (HPIPPHC) (see Table 4.7).

Table 4.6. Hierarchical Multiple Regression Analysis Results for Model 3

\begin{tabular}{|c|c|c|c|c|c|c|}
\hline \multirow{2}{*}{$\begin{array}{l}\text { Independent } \\
\text { Variables }\end{array}$} & \multirow{2}{*}{$\begin{array}{l}\text { Unstandardized } \\
\text { Coefficient } \\
\text { B }\end{array}$} & \multirow{2}{*}{$\begin{array}{l}\text { Standardized } \\
\text { Coefficient } \\
\text { Beta }\end{array}$} & \multirow[t]{2}{*}{$\mathrm{t}$} & \multirow[t]{2}{*}{ Sig. } & \multicolumn{2}{|c|}{ Collinearity Statistics } \\
\hline & & & & & Tolerance & VIF \\
\hline Constant & .536 & & 3.075 & .002 & & \\
\hline COGAO & .229 & $.240 * *$ & 4.817 & .000 & 609 & 1.642 \\
\hline ABFA & .016 & .020 & .366 & .715 & .519 & 1.926 \\
\hline REHI & .052 & .058 & .986 & .325 & .446 & 2.241 \\
\hline COORD & .123 & .143 & 2.404 & .017 & .430 & 2.324 \\
\hline MD & .181 & $.197 * *$ & 2.970 & .003 & .346 & 2.894 \\
\hline ID & .290 & $.328 * *$ & 5.696 & .000 & .458 & 2.184 \\
\hline
\end{tabular}

$\mathrm{N}=240 ; * \mathrm{p}<0.05, * * \mathrm{p}<0.01 ; \mathrm{R}^{2}=.646 ;$ Adjusted $\mathrm{R}^{2}=.637 ; \Delta \mathrm{R}^{2}$ (Change)=.049; $\mathrm{F}=71.016$ at 0.01 level; Durbin-Watson Statistics $=1.729$ and dependent variable: HPIPPHC

4.5.4 Relationships of the Local Level Support Factors and Policy Implementation Performance in Primary Health Care in Bangladesh

The results of model-4 depicts that the local support level variable Micro Level Support from Local Stakeholders (MLSLS) factors cannot influence the levels of policy implementation 
performance in primary health care (HPIPPHC). The $\mathrm{R}^{2}$ of the model- 4 was found .647 that means it can explain $65 \%$ of the variance in the level of policy implementation performance in primary health care (HPIPPHC). The local support level variable Micro Level Support from Local Stakeholders (MLSLS) from level 4 had no positive significant relationship with the levels of policy implementation performance in primary health care (HPIPPHC) in model-4 ( $\beta=.011$ at 0.825 level for Micro-Level Support from Local Stakeholders (MLSLS)) and from the ANOVA table the $\mathrm{F}=60.630$ at 0.01 level that represent the model was fit. In the final combined model-4 displays that the local support level variable Micro-Level Support from Local Stakeholders (MLSLS) had no unique statistically significant positive contribution for the relationship with policy implementation performance in primary health care (HPIPPHC) (see Table 4.7). The result specifies that the health administrators at the sub-district level health facilities in Bangladesh perceived that for effective implementation of health policy in primary care did not have the influence of local level support from local government, local administration, NGO's, private sectors and local community leaders. They can implement without the support from micro-level stakeholders. But the literature suggested that policy implementation requires support from local stakeholders and interest groups.

Besides, the $\mathrm{R}^{2}$ was not increased with the addition of local support level variable Micro Level Support from Local Stakeholders (MLSLS) in model-4 as such .481, 597, .646 and .647 for the final model-4 (see Table 4.7). In the model-4, there was no additional variance that can explain in the policy implementation performance after controlling COGAO, ABFA, REHI, COORD, $\mathrm{MD}$, and ID, $\Delta \mathrm{R}^{2}$ (Change) $=.000, \mathrm{~F}$ change $(1,232)=.049, \mathrm{p}<0.825$. Hence, the final model -4 can explain combinedly the same $65 \%$ of the variance in the level of policy implementation performance in primary health care (HPIPPHC) (see Table 4.7). The Micro Level Support from Local Stakeholders (MLSLS) had no significant effect on policy implementation performance in primary health care in Bangladesh. Table 4.8 represents the summary of the Hierarchical Multiple Regression Analysis for the four models for four level factors. The summary result says that only four factors out of seven were statistically significant and have unique contribution to the relationship for health policy implementation performance in primary care, with implementer's disposition (ID) or attitudes and responsibility of service providers reporting a higher beta value $(\beta=.329 * *$ at 0.01 level), then the following others as such Clarity of Goals and Objectives $(\beta=.238 * *$ at 0.01 level), Management Dynamics ( $\beta=.194 * *$ at 0.01 level) and Coordination $(\beta=.142 *$ at 0.05 level).

Table 4.7. Hierarchical Multiple Regression Analysis Results for Model 4

\begin{tabular}{|c|c|c|c|c|c|c|}
\hline \multirow{2}{*}{$\begin{array}{l}\text { Independent } \\
\text { Variables }\end{array}$} & \multirow{2}{*}{$\begin{array}{l}\text { Unstandardized } \\
\text { Coefficient } \\
\text { B }\end{array}$} & \multirow{2}{*}{$\begin{array}{l}\text { Standardized } \\
\text { Coefficient } \\
\text { Beta }\end{array}$} & \multirow[t]{2}{*}{$\mathrm{t}$} & \multirow[t]{2}{*}{ Sig. } & \multicolumn{2}{|c|}{ Collinearity Statistics } \\
\hline & & & & & Tolerance & VIF \\
\hline Constant & .537 & & 3.074 & .002 & & \\
\hline COGAO & .227 & $.238 * *$ & 4.669 & .000 & .585 & 1.708 \\
\hline ABFA & .015 & .019 & .349 & .728 & .517 & 1.936 \\
\hline REHI & .050 & .056 & .944 & .346 & .437 & 2.286 \\
\hline COORD & .122 & $.142 *$ & 2.381 & .018 & .429 & 2.333 \\
\hline MD & .179 & $.194 * *$ & 2.854 & .005 & .331 & 3.024 \\
\hline ID & .291 & $.329 * *$ & 5.687 & .000 & .456 & 2.192 \\
\hline MLSLS & .008 & .011 & .221 & .825 & .625 & 1.599 \\
\hline
\end{tabular}


$\mathrm{N}=240 ;{ }^{*} \mathrm{p}<0.05, * * \mathrm{p}<0.01 ; \mathrm{R}^{2}=.647 ;$ Adjusted $\mathrm{R}^{2}=.636 ; \Delta \mathrm{R}^{2}$ (Change) $=.000 ; \mathrm{F}=60.630$ at 0.01 level; Durbin-Watson Statistics $=1.729$ and dependent variable: HPIPPHC

Table 4.8. Summary of the Hierarchical Multiple Regression Analysis

\begin{tabular}{lllll}
\hline Independent Variables & Model 1 & Model 2 & Model 3 & Model 4 \\
\hline $\begin{array}{l}\text { Clarity of Goals and objectives } \\
\text { (COGAO) }\end{array}$ & $.437^{* *}$ & $.267^{* *}$ & $.240^{* *}$ & $.238^{* *}$ \\
$\begin{array}{l}\text { Adequate budget and financial } \\
\text { autonomy (ABFA) }\end{array}$ & $.125^{*}$ & .045 & .020 & .019 \\
$\begin{array}{l}\text { Resources (Human, Infrastructure } \\
\text { and Equipment) (REHI) }\end{array}$ & $.281^{* *}$ & .025 & .058 & .056 \\
$\begin{array}{l}\text { Coordination (COORD) } \\
\text { Management Dynamics (MD) }\end{array}$ & & $.208^{* *}$ & .143 & $.142^{*}$ \\
Implementers' Disposition (ID) & & $.379^{* *}$ & $.197^{* *}$ & $.194^{* *}$ \\
Micro level support from local & & & $.328^{* *}$ & $.329^{* *}$ \\
stakeholders (MLSLS) & & & & .011 \\
$\mathrm{R}^{2}$ & .481 & .597 & .646 & .647 \\
Adjusted R & & .589 & .637 & .636 \\
$\Delta \mathrm{R}^{2}$ (Change) & .474 & .116 & .049 & .000 \\
Standard Error of Estimate & .581 & .44389 & .41677 & .41762 \\
F in ANOVA & 72.905 & 69.404 & 71.016 & 60.630 \\
Sig. & .000 & .000 & .000 & .000 \\
\hline
\end{tabular}

Significant at $* \mathrm{p}<0.05, * * \mathrm{p}<0.01$ level.

\subsection{Goodness of Fit}

Table 4.8 demonstrates the summary result of hierarchical multiple regression analysis, for the four models. From the analysis, it was found that the $\mathrm{R}^{2}$ (coefficient of determination-The R-Squared) for four models as such .481, 597, .646 and .647 respectively. This implies that the first model can explain $48 \%$ the variance of the relationships for the policy implementation performance of in primary health care. Similarly, model-two 60\%, model-three $65 \%$, and model-four $65 \%$ can explain of the variance for the relationship with the dependent variable. Likewise, adjusted $\mathrm{R}^{2}$ of the four models were $.474, .589, .637$ and .636 respectively. The $\mathrm{R}^{2}$ Change for the four models were $.481, .116, .049$ and .000 . This result of $\mathrm{R}^{2}$ Change shows that the addition of one variable in model 4 had no significant effect to change the $\mathrm{R}^{2}$. Moreover, the standard error of the estimates of four models were $.50176, .44389, .41677$ and .41762 respectively which confirmed high power in estimation (Hair, Black, Babin, \& Anderson, 2010: p.209). Furthermore, ANOVA and F-ratio for overall model fit shows that all the four F-ratio was found significant at 0.01 level scoring $72.905,69.404,71.016$ and 60.630 for the four models respectively. From the analysis, it can be concluded that there was no significant change in the $\mathrm{R}^{2}$ Change in model four after adding one explanatory variable Micro Level Support from Local Stakeholders (MLSLS). Hence, overall all the models were fitted well in respect of $\mathrm{R}^{2}$, Adjusted $\mathrm{R}^{2}$, Standard error of the estimates, ANOVA and F-ratio and $\mathrm{R}^{2}$ Change (see Table 4.4, 4.5, 4.6, 4.7 and 4.8).

\subsection{The Factors Mostly Determining Health Policy Implementation Performance in Primary Health Care in Bangladesh}

Table (4.4, 4.5, 4.6, 4.7 and 4.8) shows the multivariate regression result of Hierarchical 
Multiple Regression analysis employing the seven independent variables or explanatory variables. The result says that four out of seven explanatory variables were statistically significant and had a unique contribution for the relationship ordering as per the strength as Implementer's Disposition (ID), Clarity of Goals and Objectives (COGAO), Management Dynamics (MD), and Coordination (COORD). The other three explanatory variables Resources (Equipment, Human Resources, Infrastructure, REHI), Adequate Budget and Financial Autonomy (ABFA) and Micro Level Support from Local Stakeholders (MLSLS) were found positive but not statistically significant. Hence, the variables Implementer's Disposition (ID), Clarity of Goals and Objectives (COGAO), Management Dynamics (MD), and Coordination (COORD) were the most important factors for influencing health policy implementation performance in primary health care.

The Final Form of the Models are as Follows:

Model-1: HPIPPHC $=1.221+.437 * *(\mathrm{COGAO}) \beta_{1}+.125 *(\mathrm{ABFA}) \beta_{2}+.281 * *(\mathrm{REHI}) \beta_{3}+\varepsilon_{\mathrm{i}}$

Model-2: HPIPPHC=.785+.267**(COGAO) $\beta_{1}+.208 * *(\mathrm{COORD}) \beta_{4}+.379 * *(\mathrm{MD}) \beta_{5}+\varepsilon_{\mathrm{i}}$

Model-3: HPIPPHC $=.536+.240 * *(\mathrm{COGAO}) \beta_{1}+.197 * *(\mathrm{MD}) \beta_{5}+.328 * *(\mathrm{ID}) \beta_{6}+\varepsilon_{\mathrm{i}}$

Model-4: HPIPPHC $=.537+.238 * *(\mathrm{COGAO}) \beta_{1}+.142 *(\mathrm{COORD}) \beta_{4}+.194 * *(\mathrm{MD}) \beta_{5}+.329 * *(\mathrm{ID}) \beta_{6}+\varepsilon_{\mathrm{i}}$

\section{Findings and Discussions}

The research objectives and questions were specified in the seven-research hypothesis of the study. These seven-research hypotheses were examined using exclusively field survey quantitative data by the multivariate statistical tools of hierarchical multiple regression analysis, ANOVA and Pearson correlation coefficients. Four hypotheses out of seven were fully accepted using regression standardized beta coefficient, ANOVA, and Pearson correlation and others three were partially fulfilled but not accepted. Hence, the results of hierarchical multiple regression depict that four out of seven explanatory variables were statistically significant and had a unique contribution for the relationship ordering as per the strength as Implementer's Disposition (ID), Clarity of Goals and Objectives (COGAO), Management Dynamics (MD), and Coordination (COORD). The other three explanatory variables Resources (Equipment, Human Resources, Infrastructure, REHI), Adequate Budget and Financial Autonomy (ABFA) and Micro Level Support from Local Stakeholders (MLSLS) were found a positive relationship but not statistically significant. Moreover, the variables Implementer's Disposition (ID), Clarity of Goals and Objectives (COGAO), Management Dynamics (MD), and Coordination (COORD) were the most important factors for influencing health policy implementation performance in primary health care.

\subsection{Policy Related Factors and Policy Implementation Performance}

With the second research question and its corresponding objective, three hypotheses were proposed for the identified three policy-related factors and tested using beta coefficient of hierarchical multiple regression, Pearson correlation and ANOVA and only the hypothesis one fully accepted as confirmed by the three measures containing the variable Clarity of Goals and Objectives (COGAO) had positively statistically significant association at the 
$\mathrm{p}<0.01$ level having beta coefficient of $\beta=.238 * *$ with health policy implementation performance in primary care (see Table 4.8). The two-other policy-related factors Adequate Budget and Financial Autonomy (ABFA) and Resources (Equipment, Human Resources, Infrastructure) (REHI) had no statistically significant association with health policy implementation performance having a beta coefficient of $\beta=.019$ and $\beta=.056$ respectively (see Table 4.8). Considering the Pearson correlation coefficient of the two-other policy related variables Adequate Budget and Financial Autonomy (ABFA) and Resources (Equipment, Human Resources, Infrastructure) (REHI) had strong positive correlation with health policy implementation performance in primary health care having $r=.522$ and $r=.519, \mathrm{~N}=237$, at the $\mathrm{p}<0.01$ level of significant respectively (see Table 4.2). Hence, hypothesis two and three were not fulfilled fully and not accepted. There were several prominent scholars studied in this area and they confirmed that the variable Clarity of Goals and Objectives (COGAO), one of the fundamental factors for policy implementation performance. These validations of hypothesis satisfied by the scholars who studied previously in different content and context as such; Van Meter \& Van Horn, (1975), Matland, (1995), Berman, (1978), Edwards, (1980), Martin Rein, (1983), Nakamura \& Smallwood, F., (1980), Pressman, J. L., \& Wildavsky, (1973), Palumbo, D., \& Harder, (1981), \& Sabatier \& Mazmanian, (1980).

Though the second hypothesis containing the variable adequate budget and financial autonomy (ABFA), have a positive relationship with policy implementation performance in primary health care but not significant for this study using standardized regression beta coefficient. In other studies, the hypothesis contented by the scholars in different content and context, though most of the study was qualitative case studies as such the work of; Van Meter \& Van Horn, (1975), Edwards, (1980), Voradej Chandarasorn, (2005) \& Sabatier \& Mazmanian, (1980). Hence, from the analysis, the second hypothesis was not satisfied and not accepted. Even though it was not statistically significant, it was expected that adequate budget and financial autonomy have a positive effect on the successful implementation of health policy in Bangladesh. The result of the present study revealed a contrast result with the previous studies by the scholars. These were happening because of different country context, content, time and perspectives and could be due to the change of attitude and realization that money does not matter at present days. Hence, the findings of this study were not validated and fully supported the previous studies findings.

Similarly, the third hypothesis encompassing the variable resources (Equipment, Human Resources, Infrastructure) (REHI), have a slightly positive relationship of policy implementation performance in primary health care but not statistically significant for Bangladesh. In previous studies by the scholars contented the hypothesis mostly qualitative in different content and country context as such the research study of; Berman, (1978), Lipsky, (1980), (P. Sabatier \& Mazmanian, 1980) Dussault \& Dubois, (2003), Kress, Su, \& Wang, (2016), Lassi et al., (2016), Edwards, (1980), \& Voradej Chandarasorn, (2005). Hence, from the examination, the third hypothesis was not satisfied and not accepted. But it was presumed that enough equipment, qualified health human resources, and proper infrastructure have a positive effect on the successful implementation of health policy in Bangladesh. For this study, the result uncovered that resources (Equipment, Human Resources, Infrastructure) 
(REHI) had no statistically significant relationship with policy implementation performance. These were happening because of different country context, content, time and perspectives and may well due to a bit availability of resources (Equipment, Human Resources, Infrastructure). Therefore, the results of this study were not validated and fully maintained the previous studies findings.

\subsection{Organization Related Factors and Policy Implementation Performance}

With the second research question and its corresponding objective, two hypotheses were proposed for the identified two organization related factors and tested using beta coefficient of hierarchical multiple regression, Pearson correlation and ANOVA. Both hypothesises were fully accepted as confirmed by the three measures containing the variable Coordination (COORD) and Management Dynamics (MD) had positively statistically significant association having beta coefficient $\beta=.142 *$ at the $p<0.05$ level and $\beta=.194 * *$ at the $p<0.01$ level respectively with health policy implementation performance in primary care (see Table 4.8). Regarding the Pearson correlation coefficient of the two organization related factors Coordination (COORD) and Management Dynamics (MD) had a strong positively statistically significant bivariate correlation with health policy implementation performance having $\mathrm{r}=.622$ and $\mathrm{r}=.694, \mathrm{~N}=237$, at the $\mathrm{p}<0.01$ level of significant (see Table 4.2). Moreover, from the hierarchical multiple regression model-2 explains about $60 \%$ of the variance of health policy implementation performance signifies by $R^{2}=.597$ and the $\Delta R^{2}$ (Change) $=.116$, implies that the model can explain additional $12 \%$ with the addition of two variables in the model (see Table 4.8). Therefore, hypothesis fourth and fifth were fully accepted. These validations of hypothesis fourth satisfied by the scholars who studied previously in different content and context as such; Pressman, J. L., \& Wildavsky, (1973), Laurence et al., (1984), Copeland \& Wexler, (1995), Peterlin, (2012), Peters, (1998), Edward T. Jennings \& Ewalt, (1998), Bryson, Crosby, \& Middleton Stone, (2006), \& Bouckaert, Peters, \& Verhoest, (2010). Therefore, the sound inter-organizational coordination has a significant positive effect on policy implementation performance in primary health care in Bangladesh.

These authorizations of hypothesis fifth contented by the scholars who studied previously in different content and context as such the study results of; Giacchino \& Kakabadse, (2003), Meier \& O'Toole, (2003), Voradej Chandarasorn, (2005), \& Horn \& Thiel, (2014). Hence, the findings of this study completely validated with previous work of world famous scholars as the result found in line with the previous study.

\subsection{Individual Level Factor and Policy Implementation Performance}

With the second research question and its corresponding objective, one hypothesis was proposed for the identified one individual level factor and tested using beta coefficient of hierarchical multiple regression, Pearson correlation and ANOVA and the hypotheses fully accepted as confirmed by the three measures having regression coefficient beta value $\beta=.329 * *$ at the $p<0.01$ level, demonstrating there was strong positive statistically significant relationship with health policy implementation performance in primary care (see Table 4.8). The model-3 explains about $65 \%$ of the variance of the health policy implementation performance in primary health care denoted by $\mathrm{R}^{2}=.646$. The $\Delta \mathrm{R}^{2}$ (Change) was. 049 implies 
that with the addition of one additional variable Implementer's Disposition (ID), the model can explain about $5 \%$ more of the variance to happen the health policy implementation performance (see Table 4.8). Moreover, the Pearson correlation shows that there was a strong positive correlation between Implementer's Disposition (ID), and the health policy implementation performance having $\mathrm{r}=.695, \mathrm{~N}=237$, at the $\mathrm{p}<0.01$ level of significant (see Table 4.2). Hence, the hypothesis sixth was fully satisfied and accepted for this study.

These confirmations of hypothesis satisfied by the scholars who studied previously in different content and context as such; Van Meter \& Van Horn, (1975), Berman, (1978), Edwards, (1980) \& Najam, (1995). In their early study, all the scholars found the positive attitude and responsibility for policy compliance of the implementers have a significant effect on policy implementation performance. For this study, attitude with recipients, responsibility, devotion, understanding, performing, attitude with the colleague, respect to rules and procedure, team dedication, commitment, team discipline and rely on constitutes Implementer's Disposition (ID) was hypothesized to have a positive relationship with health policy implementation performance. The result for this study depicted that Implementer's Disposition (ID) had a strong positive statistically significant association with health policy implementation performance and the finding validated the hypothesize effect and findings of past studies of the scholars.

\subsection{Local Level Support and Policy Implementation Performance}

With the second research question and its corresponding objective, one hypothesis was proposed for the identified one local level support factor and tested using hierarchical multiple regression Pearson correlation and ANOVA and the hypothesis was not fulfilled and shows that the Micro level support from local stakeholders (MLSLS) had no statistically significant relationship with health policy implementation performance having regression coefficient beta value $\beta=.011$ at the $p<0.221$ level and the seventh hypothesis was not fulfilled with the three measures and not accepted (see Table 4.8). The model-4 explains about $65 \%$ of the variance of the health policy implementation performance in primary health care denoted by $\mathrm{R}^{2}=.647$. The $\Delta \mathrm{R}^{2}$ (Change) was. 000 implies that with the addition of one additional variable Micro-level support from local stakeholders (MLSLS) in the model cannot explain more than $65 \%$ of the variance to happen the health policy implementation performance (see Table 4.8). Hence, the addition of Micro-level support from local stakeholders (MLSLS) had no extra explanatory power on health policy implementation performance in Bangladesh. Nonetheless, the Pearson correlation on other hands, shows that there was medium positive correlation between Micro level support from local stakeholders (MLSLS), and the health policy implementation performance having $\mathrm{r}=.460, \mathrm{~N}=237$, at the $\mathrm{p}<0.01$ level of significant (see Table 4.2). Hence, the hypothesis seven was not fully satisfied and accepted for this study. In various studies specially for grounded theory building several scholars like Pressman, J. L., \& Wildavsky, (1973) Shafritz \& Hyde, (2015: p.320) , Nassera Touati et al., (2007), Sabatier \& Mazmanian's, (1980: p.21),USAID, (2007), Voradej Chandarasorn, (2005). Franke \& Guidero, (2012: p.8) describes that the effective and sustained engagement and support of stakeholder requires in the implementation process at every stage for effective and successful implementation. 
All the scholars mentioned above were used mainly qualitative case studies and with their views, thoughts and empirical findings contended that local level support of stakeholders required in the implementation process for successful policy implementation. For this study, Micro-level support from local stakeholders (MLSLS) was hypothesized the positive relationship with health policy implementation performance in primary care. However, the findings of this study, that the Micro level support from local stakeholders (MLSLS) did not find satisfactory evidence to have a positive statistically significant relationship with health policy implementation performance. The reasons behind such findings could be the nature of the analysis unit and the policy related to primary health care and the street level implementers or service providers in root level. Another reason behind such result could be the institutionalization of the policy implementation for primary health care services by the sub-district level health facilities. The health care services in primary level are the unique services that provided only by the health providers. They might have thought that they can implement the primary health care policy without the support of local stakeholders. Therefore, the result of the current study has not validated the views, thoughts and empirical findings of the previous studies as the result was not in line with the previous studies.

\subsection{Policy Recommendations}

The results of the study were in line with the research objectives and research questions as discussed above. The major findings of the study reveal that the level of health policy implementation performance was found in between slightly low and high for all the predictors. Moreover, the results show that the variables Implementer's Disposition (ID), Clarity of Goals and Objectives (COGAO), Management Dynamics (MD), and Coordination (COORD) were the most important factors for influencing health policy implementation performance in primary health care in Bangladesh as they had positive significant association with health policy implementation performance in primary care. The study also intended to recommend policy implication of the findings for the related policy makers as; (a) the policy makers ought to revise the goals and objectives of the health policy that must be specific measurable achievable realistic and timebound (SMART), and disseminate the policy goals and objectives among the service providers (b) the government should allocate more financial resources, employ more health human resources and use modern technology and infrastructure for successful implementation of primary health care policies, (c) the government should emphasis on strengthening the interorganizational coordination specially between health and family planning departments, (d) the policy makers should prominence on innovation for effective health care delivery using technology, research and development and health and well-being management, (e) the policy makers would emphasis to motivate health providers regarding their responsibility, devotion and attitude to the services and recipients as the most significant determinant of health policy implementation performance in Bangladesh, (f) the government should sensitize the importance of local level support from the stakeholders specially from local government and administration for successful implementation of health policy and (g) the policy makers should ensure gender equality deploying female doctors as UH\&FPO at the sub-district level health facilities. 


\subsection{Contributions of the Study}

The study offered roughly a set of diffident contributions to the health policy implementation performance evaluation and the body of knowledge on policy implementation. The succeeding sections are arranged to summarize the theoretical and practical contributions of the study.

\subsubsection{Theoretical Contribution of the Study}

The theoretical and conceptual framework developed for this study based on several studies including the works of famous academics Graham T Allison, (1971), Pressman, J. L., \& Wildavsky, (1973), Van Meter \& Van Horn, (1975), Eugene Bardach, (1977), and Sabatier \& Mazmanian, (1980), Voradej Chandarasorn's, (2005) five and other models and top-down, bottom-up and hybrid theories of policy implementations. Grounded on the theoretical and conceptual framework seven-hypothesis were generated and tested for findings the relationship between dependent and independent variables described and discussed above, reasonably suggested the theoretical framework and contributions of the study.

The result of the study was confirmed four of the hypothesized relationship and found contrast result for the rest three hypothesis to the previous results, empirical findings, views and thoughts of the scholars. For instance, the previous studies found a positive association of policy implementation performance with adequate budgets, financial power, resources (human, infrastructure, instrument) and local level support from stakeholders. But then the findings of the study provided divergence result. The study was examined the level of health policy implementation performance in primary health care, and examined the policy related, organization related, individual level and local level support factors affecting health policy implementation performance in primary health care and determined the most influencing factors affecting health policy implementation performance in primary health care in the sub-district level health facilities in Bangladesh. Therefore, the study has discovered the importance of the theories developed on the basis of the grounded works of Allison, (1971), Pressman, J. L., \& Wildavsky, (1973), Van Meter \& Van Horn, (1975), Bardach, (1977), and Sabatier \& Mazmanian, (1980), Voradej Chandarasorn's, (2005) five and other models and top-down, bottom-up and hybrid theories of policy implementations. Thus, the findings of the study have added some innovative contribution to the body of new knowledge and theories in the literature of policy implementation, policy management, and evaluation, emphasizing on health policy implementation performance in primary health care.

\subsubsection{Practical Contribution of the Study}

Most of the previous work done in the field of policy implementation based on the qualitative methods such as case studies, empirical case studies, conceptual paper and review papers and case studies method dominated for implementation research study. It is worth note to mention that the name of the scholars in this field of policy implementation those who worked using qualitative methods namely Pressman, J. L., \& Wildavsky, (1973) case study methods; Van Meter \& Van Horn, (1975) conceptual paper; P. A. Sabatier \& Mazmanian, (1980) top-down case studies; Nakamura \& Smallwood, F., (1980) analytical concept; Martin Rein, (1983) 
conceptual paper; P. Sabatier, (1988) framework; Matland, (1995) conceptual paper; Rainey \& Steinbauer, (1999) conceptual paper; Grantham, (2001) empirical single case studies; Zahariadis \& Morgan, (2005) empirical single case studies; Brinkerhoff, (1999) multiple case studies; Tadlock et al., (2005) multiple case studies; and O’Toole Jr., (2000 \& 2004) case study methods and review. Beyond the aforementioned work of the scholars, Meier \& O'toole, (2001) and Meier \& O 'Toole, (2002) used empirical quantitative methods testing the program performance of the organization.

However, in this study, it has been systematized to use quantitative research method based on the grounded deductive theories, models and frameworks. Researchers usually use the service receivers to see the performance but, in this study, it has been looked at the perceived performance of policy implementation by the street level implementers. The sampling method for this study was used, the total population or census while most of the previous study used single and multiple case study methods and very few were used quantitative sampling methods. Many of the previous study used framework and models to explain implementation performance or success but then, in this study, it has been developed a suitable working integrated model. Moreover, most of the previous research studies which have been done in policy implementation performance in the developed country context. But in this study, it has been looked at the developing country perspectives deliberately in Bangladesh. Hence, an integrated conceptual framework was developed and assessed the factors affecting health policy implementation performance in primary health care in Bangladesh that would be expected to benefit the policy planners, implementers and the academic researchers at their respective fields.

\subsection{Direction for Future Research}

As outlined and discussed earlier, there were three plausible hypotheses not satisfied and found non-significant relationships besides the four statistically significant hypothesized relationships with health policy implementation performance, it could be an indication of future research employing more factors from the literature, grounded theory not using nomothetic approach reliant only few factors rather employing completely idiographic approach to research. The respondents of the present study were the health administrators (UH\&FPOs) at the sub-district level health complex from service providers point of view, it may well an additional sign of future research if the future researchers take the opinion of service recipients regarding health policy implementation performance in primary health care in Bangladesh.

\section{Conclusions}

The drive of the study was to assess the factors affecting health policy implementation performance in primary health care in Bangladesh. The study mainly concentrated to explore the level and relationships among the policy related, organizational related, individual level and local level support factors with health policy implementation performance in primary health care and to determine the most influencing factors affecting health policy implementation performance in primary health care in Bangladesh. A theoretical and an integrated conceptual framework and thereby four working models were developed based on 
the wide review of literature related to policy implementation theories i.e. top-down, bottom-up and hybrid, and policy implementation deductive models as such the works of well-known academics; Graham T. Allison, (1971), Pressman, J. L., \& Wildavsky, (1973), Van Meter \& Van Horn, (1975), Bardach, (1977), and Sabatier \& Mazmanian, (1980) and Voradej Chandarasorn's, (2005) five models of policy implementation. The research study discovered that female health administrators were representing only $6.7 \%$ at the sub-district level health facilities. The age structure of the respondents shows that a substantial percentage of the health administrators belonged to the young group of 30-40 $(28.3 \%)$ and $41-50(48.3 \%)$ respectively. From the descriptive statistics, the level of opinion shows that all the mean scores of the variables were found above 3.14. Furthermore, the findings of the research examined and confirmed that four out of seven hypotheses specifically $\mathrm{H} 1, \mathrm{H} 4, \mathrm{H} 5$, and $\mathrm{H} 6$ were met and fully accepted as Clarity of Goals and Objectives (COGAO), Coordination (COORD), Management Dynamics (MD), Implementer's Disposition (ID) had positively significant relationships with health policy implementation performance. The results of the study were validated with the empirical findings of the previous study. The other three hypotheses explicitly $\mathrm{H} 2, \mathrm{H} 3$, and $\mathrm{H} 7$ were not accepted as Adequate Budget and Financial Autonomy (ABFA), Resources (Equipment, Human Resources, Infrastructure, REHI), and Micro Level Support from Local Stakeholders (MLSLS) had no significant relationships with health policy implementation performance and nullified the previous studies, and these might be a reason for different content and country context. Though, these three factors are imperative for the policy implementers to implement policy at the field level. Finally, the findings of the study expected to be rebound to the benefit of society considering the contribution of new knowledge generated in the field of policy implementation, policy implementation performance, and evaluation. Moreover, the results of the study would likely to benefit the researchers to uncover the critical knowledge regarding policy implementation, implementation performance, and evaluation mentioned in the direction of future research.

\section{Acknowledgments}

I am grateful to my supervisor Asst. Professor Dr. Kasemsarn Chotchakornpant at the Graduate School of Public Administration, National Institute of Development Administration (NIDA) for his insightful guidance to prepare the research proposal and the final report of the dissertation. I am indebted to Dr. Ubaidur Rob, Bangladesh Country Director, Population Council; Professor Dr. Syed Abdul Hamid, Director, Institute of Health Economics, University of Dhaka; Associate Professor Prapon Sahapattana, Ph.D., and Asst. Professor Kasemsarn Chotchakornpant Ph.D., NIDA, Thailand for their expert opinion for content validly of the questionnaires. I am grateful to my colleagues from different cadres and friends who helped me collecting data. Subsequently, I would like to thank all the esteemed Upazila Health \& Family Planning Officers (UH\&FPO) who responded and given their perceived opinion. Most pointedly, I would like to acknowledge with heart rendering gratitude towards my wife Dr. Shamima Akter and my loving sons Mubtashim Fayyaz Rakhshan and Mubtahiz Fayyaz Rakhim for sacrificing their un compensable time. Finally. I am grateful to NIDA for providing the fund for the Ph.D. dissertation. 


\section{References}

Allison, G. T. (1971). Essence of decisions. Explaining the Cuban Missile Crisis. Boston: Little , Brown \& Company. Retrieved from http://library.wur.nl/WebQuery/clc/1850647

Bardach, E. (1977). The Implementation Game. Upper Saddle River, NJ: Prentice Hall.

Bardach, E. (2011). The Eightfold Path. A Practical Guide For Policy Analysis.

BBS. (2016). Statistical Pocket Book Bangladesh-2016. Bangaldesh Bureau of Statistics, Dhaka.

Berman, P. (1978). The study of macro and micro implementation of social policy. Public https://doi.org/10.1177/009539979102200404

Bhuyan, A., Jorgensen, A., \& Sharma, S. (2010). Taking the pulse of policy: the policy implementation assessment tool. Washington, DC: USAID.

Bouckaert, G., Peters, B. G., \& Verhoest, K. (2010). Coordination: What Is It and Why Should We Have It? In Public Sector Organizations (pp. 13-14). London: Palgrave Macmillan. https://doi.org/10.1057/9780230275256_2

Brinkerhoff, D. W. (1999). State-Civil Society networks for policy implementation in developing countries. Policy Studies Review. http://doi.org/doi:10.1111/j.1541-1338.1999.tb00844.x

Brinkerhoff, J. M., \& Brinkerhoff, D. W. (2002). Government-Nonprofit Relations in Comparative Perspective: Evolution, Themes and New Directions. Public Administration and Development, 22, 3-18. https://doi.org/10.1002/pad.202

Bryson, J. M., Crosby, B. C., \& Middleton, S. M. (2006). Design and Implementation of Cross-Sector Collaboration: Propositions from the literature. Public Administration Review, (December), 22-55. https://doi.org/10.1111/j.1540-6210.2006.00665.x

CDC National Center for Injury Prevention and Control. (2012). Brief 3 \& 4: Evaluating Policy Implementation and Evaluating Policy Content. Policy Evaluation Brief Series. Retrieved from http://www.cdc.gov/injury/about/policy/evaluation.html

Cohen, J. (1988). Statistical power analysis for the behavioral sciences. Lawrence Earlbaum Associates. http://doi.org/10.1234/12345678

Copeland, V. C., \& Wexler, S. (1995). Policy Implementation in Social-Welfare - a Framework for Analysis. Journal of Sociology and Social Welfare.

DeGroff, A., \& Cargo, M. (2009). Policy implementation: Implications for evaluation. New Directions for Evaluation. https://doi.org/10.1002/ev.313

DeVellis, R. F. (2003). Scale Development: Theory and Applications 3rd Edition. SAGE Publication Ltd.

DGHS. (2016). Health Buletin 2016. Health buletin 2016. Dhaka, Bangladesh. Retrieved 
from

http://www.dghs.gov.bd/images/docs/Publicaations/HB 2018, Vol. 8, No. 1

_2nd_edition_13_01_17.pdf

Dunn, W. N. (1981). Public policy Analysis: An introduction. Prentice-Hall, Inc., Englewood Cliffs, N.J 07632.

Dussault, G., \& Dubois, C. (2003). Human Resources for Health Human resources for health policies: a critical component in health policies. Human Resources for Health. https://doi.org/10.1186/1478-4491-1-1

Dye, T. (2012). Understanding Public Policy Policy Analysis.

Economist Intelligence Unit. (2010). Enabling efficient policy implementation. The Economist, 29.

Edward, T., Jennings, J., \& Ewalt, J. A. G. (1998). Interorganizational Coordination , Administrative Consolidation, and Policy Performance Published by: Wiley on behalf of the American Society for Public Administration Stable URL : http://www.jstor.org/stable/977551 Linked references are available on JS. Public Administration Review, 58(5), 417-428.

Edwards, G. C. (1980). Implementing public policy. Washington, D.C: Congressional Quarterly Press. https://doi.org/10.2307/2150225

Elmore, R. (1993). The Role of Local School Districts in Instructional Improvement. In Designing Coherent Education Policy: Improving the System (pp. 96-124).

Field, A. (2009). Discovering statistics using SPSS. Discovering statistics using SPSS 2nd ed.

Franke, V., \& Guidero, A. (2012). Engaging local stakeholders: A conceptual model for effective donor-community collaboration. Institute for homeland security solutions.

Giacchino, S., \& Kakabadse, A. (2003). Successful Policy Implementation: The Route to Building Self-Confident Government. International Review of Administrative Sciences. https://doi.org/10.1177/0020852303692002

Goggin, M. L. (1990). Implementation theory and practice. USA: Herper Collins Publishers.

Grantham, A. (2001). How Networks Explain Unintended Policy Implementation Outcomes: The Case of UK Rail Privatization. Public Administration.

Hair, J. F., Black, W. C., Babin, B. J., \& Anderson, R. E. (2010). Multivariate Data Analysis. Pearson Prentice Hall. https://doi.org/10.1016/j.ijpharm.2011.02.019

Harold, D. L. (1971). A Pre-View of Policy Sciences. USA: Elsevier Publishing.

Health Policy Initiative, U. (2010). Taking the Pulse of Policy, (May 2010), 50.

Hill, M., \& Hupe, P. (2002). Implementing Public Policy. Athenaeum Studi Periodici Di Letteratura E Storia Dell Antichita. https://doi.org/10.1201/9781420017007.fmatt

Horn, V., \& Thiel, V. (2014). Implementation: Putting Policy into Practice. Retrieved September from 
http://www.ru.nl/publicadministration/research/our-research-0/read-more/

Hupe, P., Hill, M., \& Nangia, M. (2014). Studying implementation beyond deficit analysis: The top-down view reconsidered. Public Policy and Administration, 29(2), 145-163. https://doi.org/10.1177/0952076713517520

Kress, D. H., Su, Y., \& Wang, H. (2016). Assessment of Primary Health Care System Performance in Nigeria: Using the Primary Health Care Performance Indicator Conceptual Framework. Health Systems \& Reform, 2(4), 302-318. https://doi.org/10.1080/23288604.2016.1234861

Lassi, Z. S., Musavi, N. B., Maliqi, B., Mansoor, N., de Francisco, A., Toure, K., \& Bhutta, Z. A. (2016). Systematic review on human resources for health interventions to improve maternal health outcomes: evidence from low- and middle-income countries. Human Resources for Health, 14(1), 10. https://doi.org/10.1186/s12960-016-0106-y

Laurence, J., O’Toole, J., \& Montjoy, R. S. (1984). Interorganizational Policy Implementation: A Theoretical Perspective. Public Administration Review, 44(6), 491-503. https://doi.org/10.2307/3110411

Lipsky, M. (1980). The Critical Role of Street-Level Bureaucrats. In Street-Level Bureaucracy:Dilemmas of the Individual Public Services.

Love, A. (2004). Implementation Evaluation. In J. Wholey, H. P. Hatry, \& K. E. Newcomer (Eds.), Handbook of Practical Program Evaluation. Jossey-Bass.

Martin, R. (1983). From Policy to Practice. (the University of Michigan, Ed.). M.E. Sharpe.

Matland, R. E. (1995). Synthesizing the Implementation Literature: The Ambiguity-Conflict Model of Policy Implementation. Journal of Public Administration Research and Theory: J-PART, 5(2), 145-174. https://doi.org/10.1093/oxfordjournals.jpart.a037242

McLaughlin, M. (1987). Learning from experience: Lessons from policy implementation. Educational Evaluation and Policy Analysis, 9(2), 171-178. https://doi.org/10.3102/01623737009002171

Meier, K. J., \& O'toole, L. J. (2001). Managerial Strategies and Behavior in Networks: A Model with Evidence from U.S. Public Education. Journal of Public Administration Research and Theory. https://doi.org/10.1093/oxfordjournals.jpart.a003503

Meier, K. J., \& O’Toole, L. J. (2003). Public Management and Educational Performance: The Impact of Managerial Networking. Public Administration Review, 63(6), 689-699. https://doi.org/10.1111/1540-6210.00332

Meier, K. J., \& O 'Toole, L. J. (2002). Public Management and Organizational Performance: The Effect of Managerial Quality. Source Journal of Policy Analysis and Management.

Meter, D. S. V., Horn, C. E. V., Van Meter, D. S., \& Van Horn, C. E. (1975). The Policy Implementation Process:A Conceptual Framework. Administration \& Society. https://doi.org/10.1177/009539977500600404 
Meyers, L. S., Gamst, G. C., \& Guarino, A. J. (2013). Applied Multivariate Research: Design and Interpretation. SAGE Publications. California, United States of America: SAGE Publications.

Meyers et al. (2005). Applied Multivariate Research.

Ministry of Health and Family Welfare. (2012). National Health Policy 2011. Retrieved from http://www.mohfw.gov.bd/index.php?option=com_docman\&task=doc_download\&gid=1475 \&lang=en

MOH\&FW. (2011). Strategic Plan for Health, Population \& Nutrition Sector Development Program (HSNSDP) 2011 - 2016. Manual. Dhaka, Bangladesh. Retrieved from https://www.bma.org.bd/pdf/strategic_Plan_HPNSDP_2011-16.pdf

Najam, A. (1995). Learning from the Literature on Policy Implementation: A Synthesis Perspective. IIASA Working Paper (Vol. WP-95-061).

Nakamura, R. T. S. F. (1980). The Politics of Policy Implementation. Policy Studies Journal.

Nakamura, \& Smallwood, F., R. T. (1980). The politics of policy implementation. St. Martin's Press.

Nassera, T. et al. (2007). Governance, Health Policy Implementation and the Added Value of Regionalization. HEALTHCARE POLICY, 2(3), 97-114. https://doi.org/10.12927/hcpol.2007.18706

NIPORT, \& Associates, M. (2014). Bangladesh Demographic and Health Survey, 328.

O'Toole, L. J. (2004). The theory-practice issue in policy implementation research. Public Administration, 82(2), 309-329. https://doi.org/10.1111/j.0033-3298.2004.00396.x

O’Toole, L. J. J. (1986). Policy Recommendations for Multi-Actor Implementation: An Assessment of the Field. Journal of Public Policy, 6(2), 181-210. S0143814X00006486

O'Toole, J. L. J. (2000). Research on Policy Implementation: Assessment and Prospects. Journal of Public Administration Research and Theory: J-PART. http://doi.org/10.2307/3525645

Ottoson, J. M., \& Green, L. W. (1987). Reconciling concept and context: Theory of implementation.

Pallant, J. (2010). SPSS survival manual (4th ed., Vol. 36). England: Mc Graw Hill, Open University Press. Retrieved from http://mcgraw-hill.co.uk/openup/chapters/0335208908.pdf

Palumbo, D., \& Harder, M. (1981). Implementing public policy. Lexington, MA: Lexington Books.

Palumbo, D. J., \& Calista, D. J. (1990). Implementation and the policy process. New York: Greenwood Press.

Peterlin, M. (2012). Policy coordination , territorial governance - towards better development 
decisions. In SEE Conference.

Peters, B. G. (1998). Managing horizontal government: the politics of co-ordination. Public Administration. https://doi.org/10.1111/1467-9299.00102

Peters, D. H., Tran, N. T., \& Adam, T. (2013). Implementation Research in Health: A $\begin{array}{lllll}\text { Practical } & \text { Guide. } & \text { Who, } & \text { Retrieved }\end{array}$ http://who.int/alliance-hpsr/alliancehpsr_irpguide.pdf

Poister, T. H. (2004). Performance Monitoring. In H. . H. \& K. E. N. (et el) J.S Wholey (Ed.), Handbook of Practical Program Evaluation. San Francisco, CA: Jossey-Bass.

Pressman, J. L., \& Wildavsky, A. (1973). Implementation (3rd ed.). Berkeley: University of California Press.

Pressman, J. L., \& Wildavsky, A. B. (1973). Implementation: how great expectations in Washington are dashed in Oakland. The Oakland Project Series.

Pulzl, H., \& Treib, O. (2007). Implementing Public Policy. In Frank Ficher et. al. (eds.) (Ed.), Handbook of Public Policy Analysis: Theory, Politics and Methods. Boca Raton, NW: Taylor \& Francis Group.

Rainey, H. G., \& Steinbauer, P. (1999). Galloping Elephants: Developing Elements of a Theory of Effective Government Organizations. Journal of Public Administration Research \& Theory. https://doi.org/10.1086/250095

Rovinelli, R. J., \& Hambleton, R. K. (1977). On the Use of Content Specialists in the Assessment of Criterion-Referenced Test Item Validity. Dutch Journal of Educational Research, 2(49-60), 49-60. http://doi.org/April 19-23, 1976

Sabatier, P. A. (1988). An advocacy coalition framework of policy change and the role of policy-oriented learning therein. Policy Sciences. https://doi.org/10.1007/BF00136406

Sabatier, P. A., \& Mazmanian, D. (1980). The implementation of public policy: A framework of analysis. Policy Studies Journal. https://doi.org/10.1111/j.1541-0072.1980.tb01266.x

Sabatier, P., \& Mazmanian, D. (1979). The Implementation of Public Policy. Policy Studies Journal. https://doi.org/10.1111/j.1541-0072.1980.tb01266.x

Sabatier, P., \& Mazmanian, D. (1980). THE IMPLEMENTATION OF PUBLIC POLICY: A FRAMEWORK OF ANALYSIS. Policy Studies Journal. https://doi.org/10.1111/j.1541-0072.1980.tb01266.x

Shafritz, J. M., \& Hyde, A. C. (2015). Classics of Public Administration. Politics (Eight). Boston USA: Cengage Learning. Retrieved from CengageBrain.com

Stewart, J. J. et. al. (2008). Public Policy: An Evolutionary Approach (3rd ed.). Boston: Thomsom Wordsworth.

Tabachnick, B. G., \& Fidell, L. S. (2013). Using multivariate statistics. (Craig \& Campanella, Eds.) (6th ed.). Pearson Educations, Inc. 
Tabachnick, B. G., \& Fidell, L. S. (2007). Using multivariate statistics. Using multivariate statistics. http://doi.org/10.1037/022267

Tadlock, B. L., Tickamyer, A. N. N. R., White, J. A., Debra, A., Pearson, N. B. J., Tadlock, B. L., ... Henderson, D. A. (2005). Leadership in an age of devolution: county commissioners role in the implementation of Appalachian Ohio's welfare reform. Public Administration Quarterly, 29, 32-53.

Thomas, R. D. (1976). Policy Analysis What Governments do, Why they do it, and What difference it makes (Second). Alabama USA: The University of Alabama Press.

UN, \& UNDP. (2015). Human Development Report 2015: Work for human development. Undp.

United Nations. (2017). World Population Prospects: The 2017 Revision, Key Findings and Advance Tables, 46. https://doi.org/10.1017/CBO9781107415324.004

USAID. (2007). Policy Reform Lessons Learned: a Review of Economic Growth Related Policy Reform Activities Policy Reform Lessons Learned. https://doi.org/10.1177/009539977500600404

Van Meter, D. S., \& Van Horn, C. E. (1975). The Policy Implementation Process: A Conceptual Framework. Administration \& Society. http://doi.org/10.1177/009539977500600404

Voradej, C. (2005). An Integrated Theory of Public Policy Implementation. Bangkok: TURA.

Weimer, D. L., \& Vining, A. R. (2005). Policy Analysis: Concepts and Practice. David L Weimer. https://doi.org/10.2307/3325122

WHO. (2016). Monitoring the health goal: Indicators of overall progress. In Mointoring Health for the SDGs.

Wikipedia. (2017). Global Health Policies.

Wildavsky, A. (1979). The Art and Craft of Policy Analysis (1st ed.). Palgrave Macmillan UK. https://doi.org/10.1007/978-1-349-04955-4

Zahariadis, N., \& Morgan, L. (2005). Local Government and the Implementation of Alabama's Economic Development Policy. Public Administration Quarterly. http://doi.org/Article

\section{Copyright Disclaimer}

Copyright for this article is retained by the author(s), with first publication rights granted to the journal.

This is an open-access article distributed under the terms and conditions of the Creative Commons Attribution license (http://creativecommons.org/licenses/by/4.0/). 